\title{
Time series and beyond: multifaceted plankton research at a marine Mediterranean LTER site
}

\author{
Adriana Zingone', Domenico D’Alelio', Maria Grazia Mazzocchi', Marina \\ Montresor', Diana Sarno', LTER-MC team' \\ I Stazione Zoologica Anton Dohrn, Villa Comunale, 80121 Naples, Italy \\ Corresponding author: Adriana Zingone (zingone@szn.it)
}

Academic editor: A. Lugliè | Received 23 October 2018 | Accepted 6 February 2019 | Published 3 May 2019

http://zoobank.org/02909248-83AC-426D-B87B-2FEED31EB788

Citation: Zingone A, D’Alelio D, Mazzocchi MG, Montresor M, Sarno D, LTER-MC team (2019) Time series and beyond: multifaceted plankton research at a marine Mediterranean LTER site. In: Mazzocchi MG, Capotondi L, Freppaz M, Lugliè A, Campanaro A (Eds) Italian Long-Term Ecological Research for understanding ecosystem diversity and functioning. Case studies from aquatic, terrestrial and transitional domains. Nature Conservation 34: 273-310. https:// doi.org/10.3897/natureconservation.34.30789

\begin{abstract}
Plankton are a pivotal component of the diversity and functioning of coastal marine ecosystems. A long time-series of observations is the best tool to trace their patterns and variability over multiple scales, ultimately providing a sound foundation for assessing, modelling and predicting the effects of anthropogenic and natural environmental changes on pelagic communities. At the same time, a long time-series constitutes a formidable asset for different kinds of research on specific questions that emerge from the observations, whereby the results of these complementary studies provide precious interpretative tools that augment the informative value of the data collected. In this paper, we review more than 140 studies that have been developed around a Mediterranean plankton time series gathered in the Gulf of Naples at the station LTER-MC since 1984. These studies have addressed different topics concerning marine plankton, which have included: i) seasonal patterns and trends; ii) taxonomic diversity, with a focus on key or harmful algal species and the discovery of many new taxa; iii) molecular diversity of selected species, groups of species or the whole planktonic community; iv) life cycles of several phyto- and zooplankton species; and v) interactions among species through trophic relationships, parasites and viruses. Overall, the products of this research demonstrate the great value of time series besides the record of fluctuations and trends, and highlight their primary role in the development of the scientific knowledge of plankton much beyond the local scale.
\end{abstract}

\section{Keywords}

phytoplankton, zooplankton, time series, long-term research, LTER, Mediterranean Sea

Copyright Adriana Zingone et al. This is an open access article distributed under the terms of the Creative Commons Attribution License (CC BY 4.0), which permits unrestricted use, distribution, and reproduction in any medium, provided the original author and source are credited. 
...time-series programs act
as intellectual flywheels that create and
sustain ever larger, complementary
programs where the scientific outcome
of the integrated effort is much larger
than the sum of its parts

David Karl (2010)

\section{Introduction}

Long-term ecological research is recognized to contribute prominently to scientific advances as well as to inform environmental policy, which makes investments in continuous observations highly cost-effective (Edwards et al. 2010, Hughes et al. 2017). Yet, long-term studies have often been derogatorily tagged as 'routine monitoring', only aimed at recording natural events, whereby the sampling scheme that repeats over time with the same sustainable modality would hardly deem to deserve consideration alongside scholarly scientific activities. In terms of publications, observational activities are also considered scarcely rewarding, or likely to produce only descriptive papers. As a matter of fact, long-term time series are less than what would be needed and their spatial coverage is extremely limited (Koslow and Couture 2013). In the marine environment, few programs among the twentieth-century time-series have lasted more than a few decades (Duarte et al. 1992) probably because of their higher inherent costs and lower accessibility compared to the terrestrial environment. Especially in the case of plankton, the dominance of microbial life, which is characterized by small temporal and spatial scales in life cycles and distributions (Ribera d'Alcalà 2019) imposes a sampling frequency that is hardly compatible with the logistic and economic constraints of marine research. In fact, long-term ecological studies are less numerous in the world seas than in freshwater and terrestrial ecosystems (e.g., Mirtl et al. 2018), and they are mostly coastal and only in a few cases include the study of plankton.

Nonetheless, remarkable examples exist of the crucial role of time series as a baseline for the definition of the marine ecosystem status change and the understanding of the impact of climatic and anthropic forces on the structure and function of oceanic ecosystems (McGowan 1990, Karl 2010, Koslow and Couture 2013, Cloern et al. 2016). Time-series analysis has highlighted long-term changes and regime shifts that are at the basis of the fluctuations for plankton and fish populations in relation to climate oscillations in the north Atlantic (Beaugrand 2004, Edwards et al. 2010, Harris 2010) and in the Pacific (Venrick et al. 1987, Karl et al. 2001), which has been made possible by such regular and persistent surveys as the Continuous Plankton Recorder program (Reid et al. 2003), the long-term observations in San Francisco Bay (Cloern and Jassby 2012) and at the CALCOFI and station ALOHA programs in the North Pacific Ocean (Karl et al. 2001, Koslow et al. 2011). 
In the studies mentioned above, the data collected over many years have mainly been used to highlight interannual patterns, episodic events and long-term changes in the system. On the other hand, it is rarely taken into account that, while recording changes over time, a sustained sampling plan can help to gather fundamental information on the biology of the species and illuminate the mechanisms of their succession and the relationships among the components of the system. In addition, the precious infrastructural asset of a time series provides a backbone for complementary studies that are stimulated by questions stemming from the results of continuous observations (Karl 2010, Zingone et al. 2010b).

This paper is an overview of a series of studies that have been produced in relation to plankton observations conducted at the Long Term Ecological Research site "MareChiara" (LTER-MC) in the Gulf of Naples (Mediterranean Sea) since its establishment in 1984. These studies include both ecological investigations aimed at tracing the time variability of the pelagic system and complementary research based on experiments or additional observations flanking the routine monitoring for shorter periods of time. The latter complementary studies were prompted by the idea that the interpretation of observational data must be grounded in a deep understanding of the diversity, biological assets and ecological interactions of plankton populations, which is the key to the prediction of the response of natural populations to changing scenarios. Our aim is to highlight the fundamental contribution of time series to the development of plankton knowledge that can be of general interest much beyond the local scale.

\section{The research site: general characteristics}

The Gulf of Naples (GoN) extends between $40^{\circ} 50^{\prime} \mathrm{N}, 40^{\circ} 32^{\prime} \mathrm{N}, 13^{\circ} 52^{\prime} \mathrm{E}, 14^{\circ} 28^{\prime} \mathrm{E}$ in the Mid Tyrrhenian Sea, with an area of ca $870 \mathrm{~km}^{2}$ and an average depth of $170 \mathrm{~m}$ (Fig. 1). A population of about 4 million people lives in the coastal area, which has been inhabited since pre-Roman times. Large-scale industrial activity is today reduced, while small and medium enterprise activities are significant and growing. For several years, urban and industrial discharges have largely been submitted to different types of treatments. However, some highly impacted areas are still present, sometimes located close to relatively pristine localities that are part of Marine Protected Areas (http:// www.parks.it/indice/RM/map.php?reg=15) (Tornero and Ribera d'Alcalà 2014). Besides scattered municipal effluents, modest freshwater inputs are provided by the Sarno River from the southern coast and the Volturno River from the adjacent Gulf of Gaeta to the North, which results in high salinity values (>38) often also close to shore.

First studies on the plankton of the GoN predate the foundation of the Stazione Zoologica Anton Dohrn of Naples (SZN) in 1872 (e.g., Costa 1858). In the following decades studies on plankton biodiversity were occasionally conducted with different objectives, and included taxonomic studies on copepods (Giesbrecht 1892) and ecological studies focused on the phenology of microplankton species (Issel 1934, Indelli 1944, De Angelis 1958) and on zooplankton distribution (Hure and Scotto di Carlo 1968). 


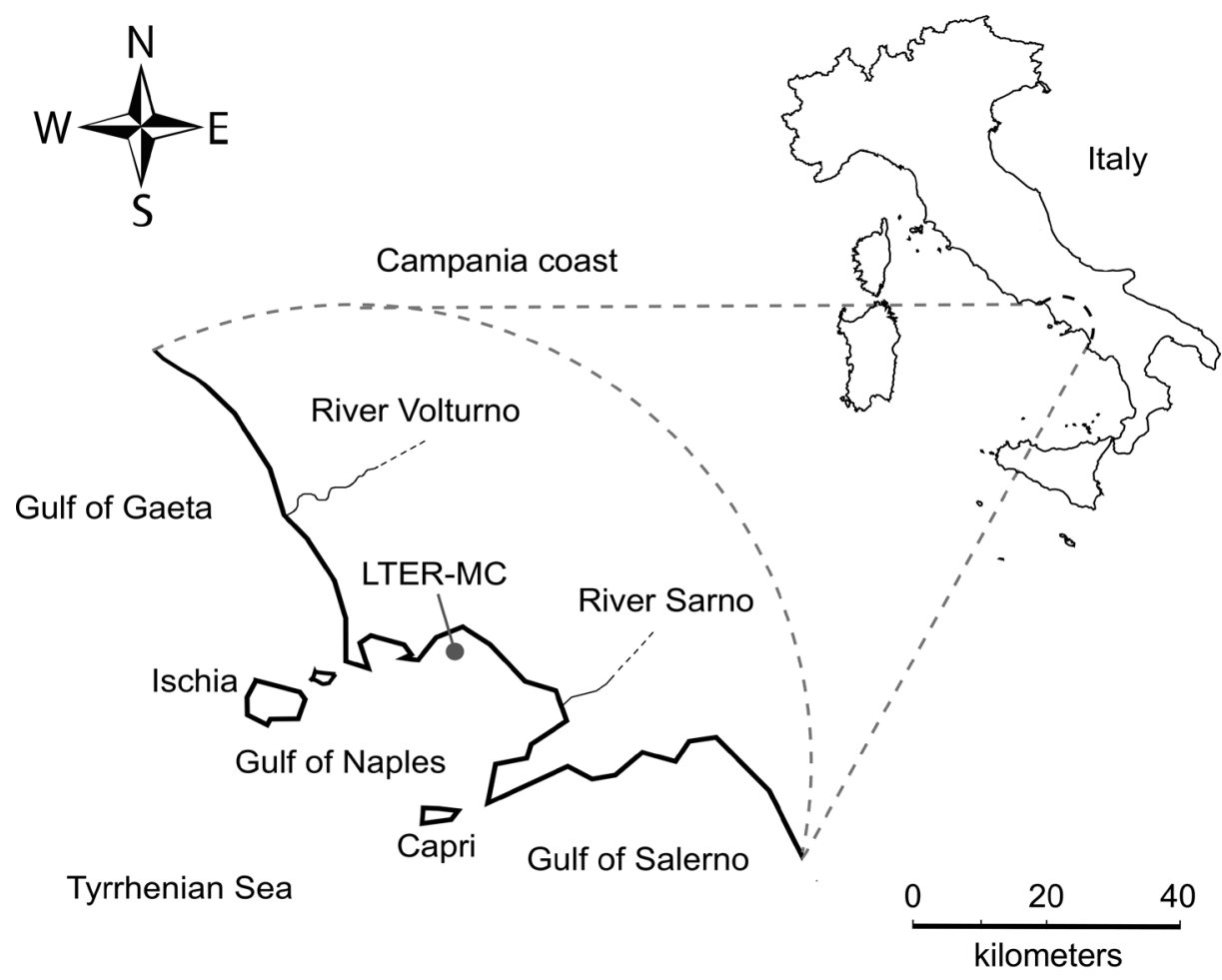

Figure I. Map of the Gulf of Naples with the location of the station LTER-MC.

Yet regular ecological researches into the planktonic system of the GoN did not start until the 1970's (Carrada et al. 1981, 1982). Since 1984 these researches have mainly been based on data collected fortnightly (until 1991) or weekly (1995 to date) at the site MareChiara (Scotto Di Carlo et al. 1985, Ribera d'Alcalà et al. 2004), which in 2006 became part of the Italian, European and international LTER networks as LTER-MareChiara (LTER-MC). Research at this single point has been complemented over the years by several sampling campaigns and studies expanding over the whole area of the GoN and at times in the adjacent Gulfs (Marino et al. 1984, Ribera d'Alcalà et al. 1989, Zingone et al. 1990, 1995a, Ragosta et al. 1995, Iermano et al. 2012, Cianelli et al. 2017).

The station LTER-MC is located 2 nautical miles off the coast of the city of Naples in an area that can be alternatively influenced by the eutrophic coastal zone and the oligotrophic waters of the mid Tyrrhenian Sea (Fig. 1). Based on the data from a series of weekly sampling cruises in the inner Bay of Naples in summer 1983 (Zingone et al. 1990), the site was selected so as to avoid the conditions more directly reflecting the most intensive nutrient inputs from the southeastern coast of the inner Bay, and to capture the variability deriving from the exchange with the offshore waters. In fact, estimates of primary production conducted over the first part of the time series range from 
Table I. Environmental and biological variables at station LTER-MC (1984-2014). All values refer to surface waters, except zooplankton abundance which refers to 0-50 m layer of the water column.

\begin{tabular}{|c|c|c|c|c|c|}
\hline & Temperature $\left({ }^{\circ} \mathrm{C}\right)$ & Salinity & $\begin{array}{c}\text { Chlorophyll } a \\
\left(\mu \mathrm{g} \mathrm{L}^{-1}\right)\end{array}$ & $\begin{array}{l}\text { Phytoplankton } \\
\left(\text { Cells } \mathrm{mL}^{-1}\right)\end{array}$ & $\begin{array}{l}\text { Zooplankton } \\
\text { (Ind. } \mathrm{m}^{-3} \text { ) }\end{array}$ \\
\hline Minimum & 13.2 & 36.2 & 0.1 & $7.5 \times 10$ & $1.1 \times 10^{2}$ \\
\hline Maximum & 28.9 & 38.3 & 26.8 & $2.2 \times 10^{5}$ & $2.3 \times 10^{4}$ \\
\hline Median & 19.6 & 37.7 & 1.1 & $5.7 \times 10^{3}$ & $1.3 \times 10^{3}$ \\
\hline
\end{tabular}

$260 \mathrm{~g} \mathrm{C} \mathrm{m}^{-2} \mathrm{yr}^{-1}$ in the period $1984-1991$ to $151 \mathrm{~g} \mathrm{C} \mathrm{m}^{-2} \mathrm{yr}^{-1}$ in the years $1997-2000$ (Pugnetti et al. 2006), which ranks the study area as oligo-mesotrophic (Nixon 1995). Research on the spatial representativeness of station LTER-MC has shown that the site is more affected by coastal than offshore waters and can occasionally be influenced by the nearby Gulf of Gaeta (Carrada et al. 1981, Iermano et al. 2012), whereas it does not seem significantly affected by the Sarno River (Cianelli et al. 2017). On the other hand, complementary research conducted on a wider area (e.g. Marino et al. 1984, Ragosta et al. 1995, Zingone et al. 1995a) indicates that environmental conditions in the inner Gulf of Naples are quite distinct from the nearby mid-Tyrrhenian coasts.

The dataset collected at the LTER-MC site since 1984 includes physical (temperature and salinity), chemical $\left(\mathrm{O}_{2}, \mathrm{NO}_{2}, \mathrm{NO}_{3}, \mathrm{NH}_{4}, \mathrm{PO}_{4}, \mathrm{SiO}_{4}\right)$ and biological (chlorophyll $a$, phytoplankton and mesozooplankton) data, all concerning different depths of the water column except phytoplankton which are analyzed in surface waters and mesozooplankton which are collected in the $0-50 \mathrm{~m}$ depth layer (Table 1). A number of other variables have been added over the years, including pigment spectrum by High Performance Liquid Chromatography (HPLC) since 1996 and, since 2007, particulate Organic Carbon (POC), Total Nitrogen and Phosphorous (TN e TP), Dissolved Organic Carbon (DOC), bacteria and picoplankton by flow-cytometry and mesozooplankton carbon and nitrogen content. Data over relatively long periods were also collected for microzooplankton (March 1984-March 1985, September 1996-December 2009), ${ }^{14} \mathrm{C}$ primary production (1984-1989 and 2007) and egg production and viability in the copepod Centropages typicus Krøyer, 1849 (1995-2015).

\section{Temporal variability at station LTER-MC}

Tracing the ecosystem variability over decadal scales is the distinctive essence of longterm research and the only approach that allows for discerning regular patterns, trends and shifts occurring in the environment. In long-term studies, one of the primary questions is whether significant changes occur in the overall system or in some of its components, which at LTER-MC has so far been addressed over the years 1984-2006. In that period, a pronounced interannual variability was evident in all environmental variables, with only a few significant trends, e.g., increase in summer temperature and decrease in chlorophyll $a$ concentrations (Mazzocchi et al. 2011, 2012). Chlorophyll 
markedly declined until 2002 (Zingone et al. 2010a), followed by a weak positive trend from 2003 to 2006 (Mazzocchi et al. 2012). Since 1995, phytoplankton increased in cell numbers but decreased in average cell size (Ribera d'Alcalà et al. 2004) mainly because of a decrease, across the years, in the proportion of larger vs. smaller diatom species (Fig. 2). The decrease for average cell size was evident until the early 2000s but a trend reversal has been observed in recent years (Sarno and Zingone unpubl. data in Morabito et al. 2018).

Copepods are the most numerous among the zooplankton groups and shape the patterns of the entire community. They showed higher abundances in the 1980s than in the two successive decades; this trend reversed in the years 2004-2006, mainly due to the increase of the calanoids Paracalanus parvus (Claus, 1863), Acartia clausi Giesbrecht, 1889 and Centropages typicus (Mazzocchi et al. 2012). The latter two species showed changes in their phenology with a significant anticipation of their population cycle in relation to positive temperature anomalies, a typical "earlier when warmer" response observed at different latitudes (Mackas et al. 2012). The decrease in chlorophyll concentrations suggests that station LTER-MC has acquired less coastal characteristics over the years, a signal that is also seen in the disappearance of a few copepod species typical of confined areas and increased abundance of species that thrive in offshore waters (Mazzocchi et al. 2012).

Over a longer time scale, the comparison with previous investigations in the GoN of the early 1930s showed essential changes in the tintinnid (ciliates) community in terms of dominant species (Modigh and Castaldo 2002) and in the occurrence of dinoflagellates species of the genus Tripos (as Ceratium) as a response to local warming (Tunin-Ley et al. 2009).

The interannual variability at station LTER-MC is remarkable, but it is the seasonal forcing that plays the main role in shaping the local pelagic system by deeply affecting the environmental features (Ribera d'Alcalà et al. 2004) and the plankton assemblages, from phytoplankton (Zingone et al. 1990, 1995a, 2003, 2010b) to microzooplankton (Modigh 2001, Modigh and Castaldo 2002) and mesozooplankton (Mazzocchi and Ribera d'Alcalà 1995, Mazzocchi et al. 2011, 2012). The only exception seems to be represented by the quite constant abundance of picoplankton, which, however, was studied over a single annual cycle (Modigh et al. 1996). The depiction of the average annual cycle of plankton at the sampling site is supported by long-term records which highlight the recurrence of regular patterns during most of the time series (Fig. 3). The comparison of the average seasonal cycle of zooplankton (1984-2006) with that of other five Mediterranean time-series at stations encompassing a wide range of trophic status has revealed that local drivers are dominant over large-scale climate influence for these coastal stations (Berline et al. 2012).

In thoroughly mixed water column conditions, minimum annual concentrations of chlorophyll in December-January, with a dominance of nanoflagellate species, are generally followed by late winter increase in February-March, mainly driven by large colonial diatoms which include several Chaetoceros species, Pseudo-nitzschia delicatissima (Cleve) Heiden and Thalassionema bacillaris (Heiden) Kolbe. These winter blooms 


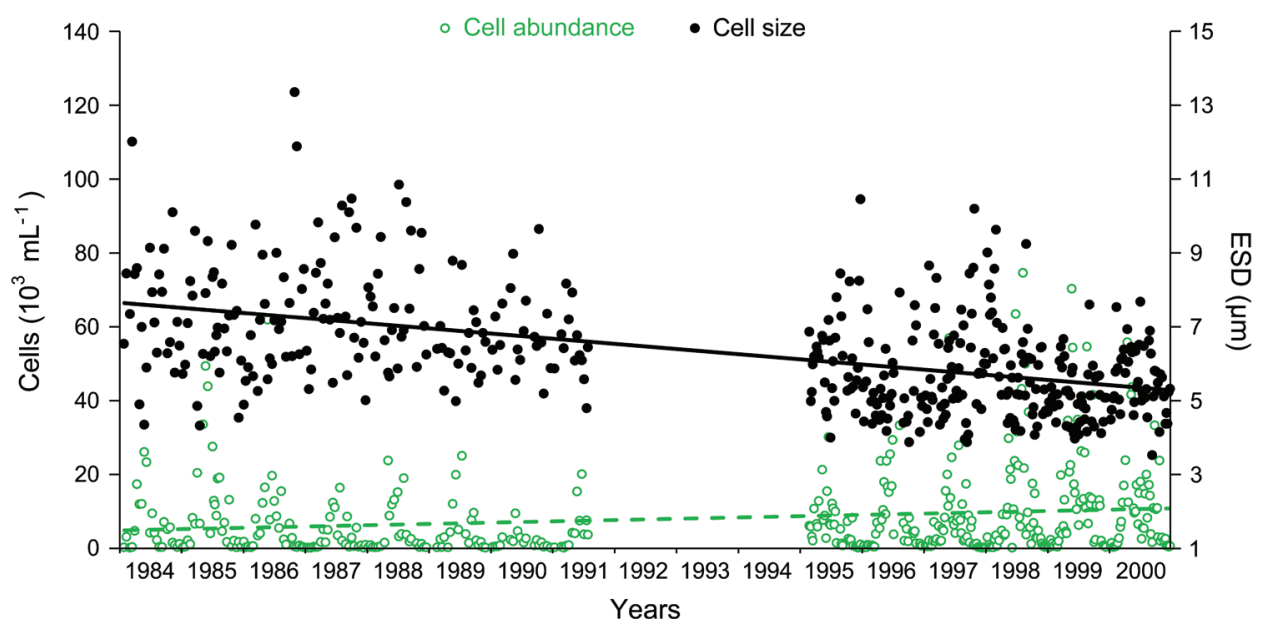

Figure 2. Trends in cell number and size of phytoplankton species at station LTER-MC. Redrawn from Ribera d'Alcalà et al. (2004). The marked decrease in cell size mainly reflected the decrease of larger diatom species and the increase of small-sized ones. ESD: Equivalent Spherical Diameter.

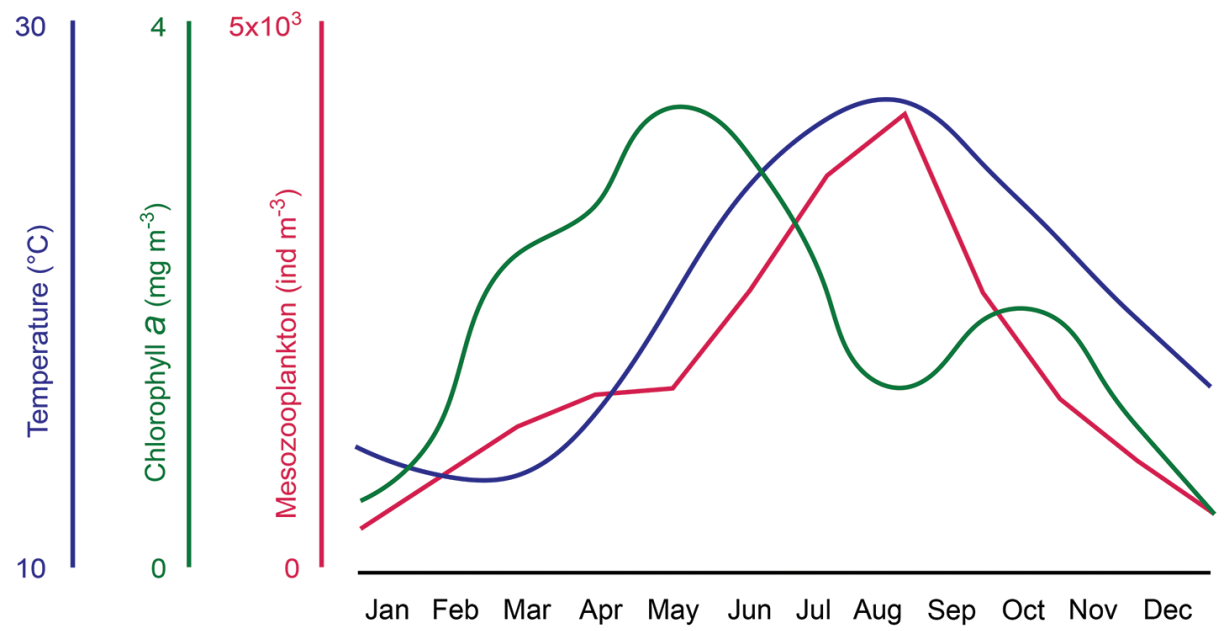

Figure 3. A schematic, averaged seasonal cycle of temperature, chlorophyll $a$ and mesozooplankton abundance at station LTER-MC as recorded in the period 1984-2014.

are allowed by the non-limiting light amount especially under stable meteorological conditions and are reinforced by freshwater inputs contrasting intense vertical mixing (Zingone et al. 2010b). The reduced grazing due to the annual minima for micro- and mesozooplankton also contributes to the build-up of the winter biomass. In the winter ciliate assemblage, autotrophic species (Mesodinium) show the highest contribution, 
while among metazoans copepods occur with numerous small-sized species (e.g., Clausocalanus, Calocalanus, Ctenocalanus vanus Giesbrecht, 1888, Oithona, oncaeids and corycaeids) and a few larger-sized $(>1.5 \mathrm{~mm})$ genera which thrive in deep offshore waters and are brought to the coastal site by the winter water mass circulation. The winter zooplankton are also characterized by a high percentage contribution of appendicularians and meroplankton, the latter group likely reflecting the intense reproductive activity of benthic organisms, which indicates that phytoplankton blooms in this season fuel the zoobenthos rather than being exploited by the scarcely abundant holoplankton.

Spring is the period of growth of the whole plankton compartment in the GoN, with a conspicuous phytoplankton peak confined to surface waters generally occurring in May, mainly caused by diatoms (e.g. Skeletonema pseudocostatum Medlin and Leptocylindrus aporus (F.W. French \& Hargraves) Nanjappa \& Zingone and phytoflagellates. Spring also sees the highest biomass of ciliates, which are dominated by the mixotrophic choreotrichs, and a copepod peak dominated by Acartia clausi in early spring followed by Centropages typicus in late spring-early summer.

In summer, with the annual peak of surface temperature $\left(26{ }^{\circ} \mathrm{C} \pm 1.5^{\circ} \mathrm{C}\right.$ in August), phytoplankton are mainly characterized by intense blooms of small-sized, often non-colonial diatom species (e.g., Chaetoceros tenuissimus Meunier) and of phytoflagellates, along with an increase of dinoflagellate biomass. Ciliates are represented by a variety of mixotrophic Strombidium, while mesozooplankton show the highest abundance and the lowest diversity of the entire year, along with the dominance of cladocerans (Penilia avirostris Dana, 1842) and copepods (mainly Paracalanus parvus).

The water column stratification disrupts in autumn, when depth-integrated temperature and salinity reach their maximum annual values. Phytoplankton show a less regular third annual peak in October-early November which is driven by recurrently stable weather conditions (Saint Martin's summer) that allow the exploitation of nutrients of terrestrial origin and mainly contributed by colonial diatoms (Leptocylindrus spp., Chaetoceros socialis Lauder, Thalassiosira rotula Meunier, etc.) (Zingone et al. 1995a). Among ciliates, the autotrophic Mesodinium rubrum (Lohmann, 1908) and the mixotrophic Strombidium spp. and Tontonia spp. occur with high concentrations. The copepods Temora stylifera (Dana, 1849), Clausocalanus furcatus (Brady, 1883) and Oithona plumifera Baird, 1843, together with chaetognaths, appendicularians and doliolids, account for most mesozooplankton abundance in this period of the year.

Overall, in spite of the high interannual variability observed in environmental variables, the different phases of the annual cycle are remarkably regular for the whole community structure and for the most common species of all planktonic compartments (Mazzocchi and Ribera d'Alcalà 1995, Modigh 2001, Modigh and Castaldo 2002, Ribera d'Alcalà et al. 2004, Mazzocchi et al. 2011). This feature highlights the resilience of coastal communities, which may favor their persistence over time (Mazzocchi et al. 2012, Cianelli et al. 2017). Recurrent species-specific seasonal patterns are observed not only in species of the copepod genera Clausocalanus and Oithona (Mazzocchi and Ribera d'Alcalà 1995, Castellani et al. 2015), but also in several phytoplankton taxa, such as the dinoflagellate Tripos (as Ceratium, Tunin-Ley et al., 2009), the diatom Pseudo-nitzschia 
(Ruggiero et al. 2015), cryptomonads (Cerino and Zingone 2006) and numerous other species (Zingone and Sarno 2001, Ribera d'Alcalà et al. 2004), which suggests that the seasonal succession is mainly regulated by biological factors, such as life-cycle processes, species-specific physiological performances and inter-specific interactions.

\section{Plankton diversity at LTER-MC}

LTER-MC is one of the few sites where marine plankton diversity is regularly monitored at the species level, with routine sample observations complemented by detailed taxonomic studies based on microscopy and molecular analyses. This peculiar approach stems from the conviction that a sound taxonomic knowledge and a clear definition of the ecological units of interest (i.e., species identification) are fundamental to the study of seasonal and long-term variability of plankton communities, to assess the conditions in which phyto- and zooplanktonic species occur and succeed, and, ultimately, understand the pelagic ecosystem functioning. These principles also explain the attention paid to quality control procedures of both diversity and chemical physical data (Zingone et al. 2015, Sabia et al. 2019). Indeed, the relevance of precise identification is fully supported by the results so far obtained on the taxonomic and molecular diversity of the GoN plankton, as detailed in the following.

Studies on plankton diversity in the GoN boast an ancient tradition dating back to the beginning of the XIX century (Delle Chiaje 1823, Costa 1858) and have intensified following the SZN foundation (Daday 1888, Giesbrecht 1892, Schröder 1900). Much higher attention has been paid to taxonomy of the GoN plankton since the start of the LTER-MC project, which has led to the clear demonstration of the high diversity of these assemblages, with more than 750 microalgal and 212 mesozooplankton taxa recorded over the years. These numbers are certainly underestimated, particularly for protists, because many groups are still in need of detailed taxonomic investigation, but also for planktonic metazoans (Fig. 4), which also need deep investigation at the molecular level (Di Capua et al. 2017) and are recently revealing a high level of cryptic diversity (Hirai et al. 2017, Kasapidis et al. 2018). A current view is that hotspots of diversity correspond to hotspots of expert taxonomists, a joke that points to the lack of objective criteria for the comparison of plankton diversity among different sites. Nonetheless, it is tempting to hypothesize that the GoN presents suitable characteristics to host a high biodiversity for plankton organisms. In fact, the Mediterranean Sea confers the area subtropical characteristics despite its temperate latitude, while the fertility of coastal waters may act as an incubator of diversity for a high number of species, including those from offshore waters that are frequently driven into the Gulf. The interplay of hydrography, climate and trophic conditions likely creates optimal conditions for a high number of species to coexist in the area, a hypothesis that comparative studies with objective molecular methods will allow to test over coming years.

The taxonomic insights on the LTER-MC plankton have concerned particularly microalgae, which remain the least known plankton compartment - the smaller the 


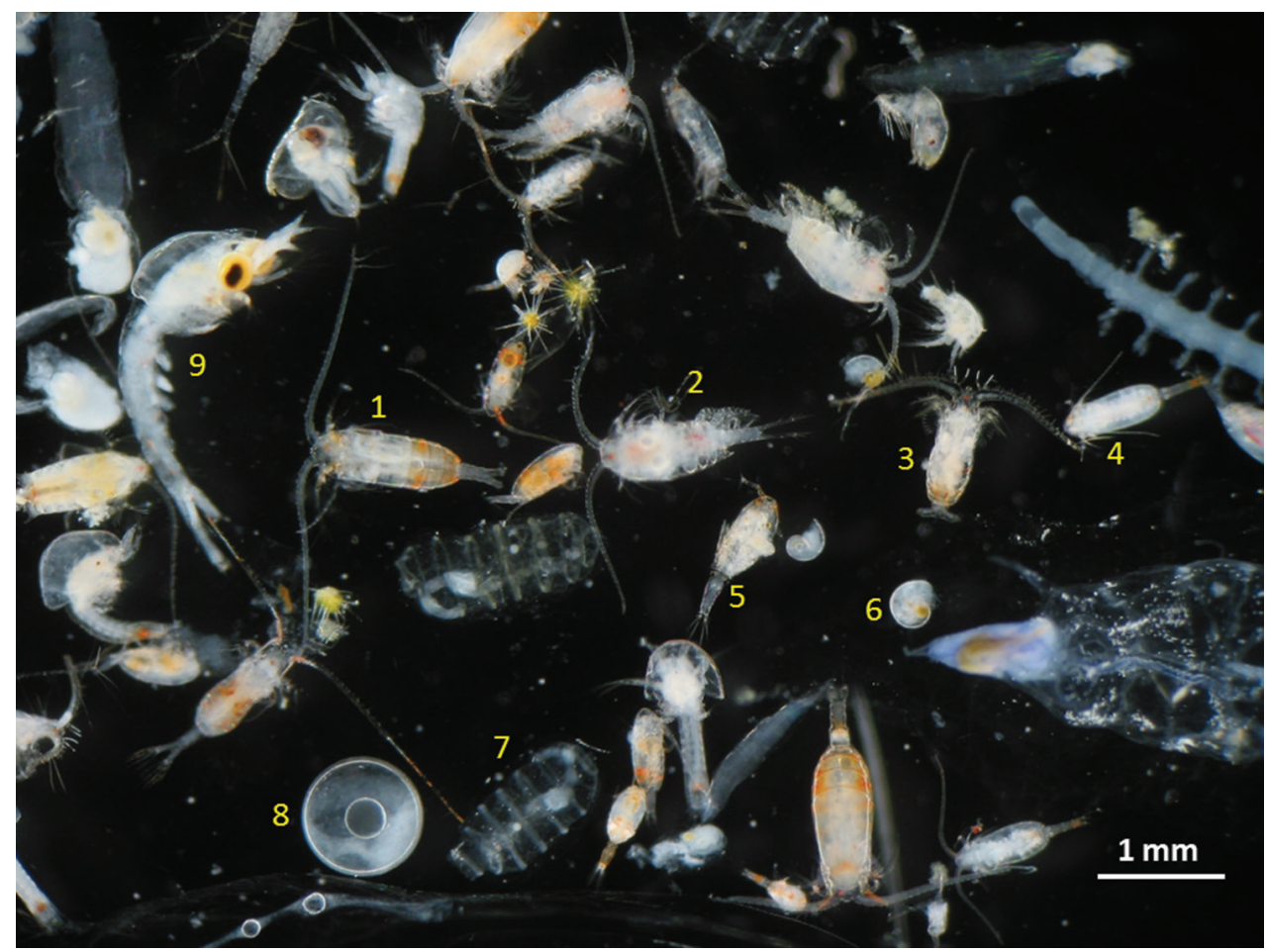

Figure 4. A mixed zooplankton sample from station LTER-MC with indicated some common taxa. Copepods: I Calanidae $\mathbf{2}$ Temora stylifera $\mathbf{3}$ Calocalanus $\mathbf{4}$ Clausocalanus $\mathbf{5}$ Oncaeidae $\mathbf{6}$ gastropod larva $\mathbf{7}$ doliolid $\mathbf{8}$ fish egg $\mathbf{9}$ decapod larva.

organism, the larger the taxonomic deficit. Cultivation of microalgal strains obtained from natural samples under controlled laboratory conditions, introduced at SZN in the 1980's, has been a powerful tool for the characterization of poorly known species. Flagellates hardly identified in fixed material were investigated at LTER-MC over their seasonal cycle using the Serial Dilution Culturing method (Throndsen 1978, Cerino and Zingone 2006), which eventually turned out to be a valuable source of material for deeper taxonomical and ecophysiological investigations. In addition, electron microscopy frequently coupled with cultivation allowed taxonomic insights of interest much beyond the GoN, like the rediscovery of Mediterranean flagellate species never found since their early description (Throndsen and Zingone 1988, 1994, Zingone et al. 1995b), and the description of calcareous resting stages of dinoflagellates and their assemblages in sediments from the GoN (Montresor et al. 1993, 1994, D'Onofrio et al. 1999).

Over the years, the regular observations of plankton samples from LTER-MC and the development of taxonomic expertise at SZN have allowed for spotting organisms not readily classifiable, paving the way for the re-description of ill-defined taxa and the discovery and formal description of more than 20 microalgal species new to science. These latter studies, often integrating the resting stage features as a further taxonomic 
Table 2. Phytoplankton species originally described with different methods from LTER-MC and surrounding waters. C: cultivation, M: Light and Electron Microscopy, MB: Molecular Biology, LC: Life Cycle studies, RS: Resting Stage description.

\begin{tabular}{|c|c|c|}
\hline Species & Methods & References \\
\hline \multicolumn{3}{|l|}{ Diatoms } \\
\hline Bacteriastrum parallelum Sarno, Zingone \& Marino & $\mathrm{C}, \mathrm{M}$ & Sarno et al. 1997 \\
\hline Chaetoceros throndsenii (Marino, Montresor \& Zingone) & $\mathrm{C}, \mathrm{M}, \mathrm{RS}$ & Marino et al. 1987, Marino et al. 1991 \\
\hline \multicolumn{3}{|l|}{ Marino, Montresor \& Zingone } \\
\hline Leptocylindrus aporus (F.W. French \& Hargraves) & $\mathrm{C}, \mathrm{M}, \mathrm{MB}$ & French and Hargraves 1986, Nanjappa \\
\hline Nanjappa \& Zingone & & et al. 2013 \\
\hline Leptocylindrus convexus Nanjappa \& Zingone & $\mathrm{C}, \mathrm{M}, \mathrm{MB}, \mathrm{RS}$ & Nanjappa et al. 2013 \\
\hline Leptocylindrus hargravesii Nanjappa \& Zingone & $\mathrm{C}, \mathrm{M}, \mathrm{MB}, \mathrm{RS}$ & Nanjappa et al. 2013 \\
\hline Pseudo-nitzschia mannii Amato \& Montresor & $\mathrm{C}, \mathrm{M}, \mathrm{MB}, \mathrm{LC}$ & Amato and Montresor 2008 \\
\hline Skeletonema dohrnii Sarno \& Kooistra & $\mathrm{C}, \mathrm{M}, \mathrm{MB}$ & Sarno et al. 2005 \\
\hline Tenuicylindrus belgicus* (Meunier) Nanjappa \& Zingone & $\mathrm{C}, \mathrm{M}, \mathrm{MB}$ & Meunier 1915, Nanjappa et al. 2013 \\
\hline \multicolumn{3}{|l|}{ Dinoflagellates } \\
\hline Alexandrium mediterraneum U. John & $\mathrm{C}, \mathrm{M}, \mathrm{MB}$ & John et al. 2014 \\
\hline Alexandrium tamutum Montresor, Beran \& U. John & $\mathrm{C}, \mathrm{M}, \mathrm{MB}$ & Montresor et al. 2004 \\
\hline Azadinium dexteroporum Percopo \& Zingone & $\mathrm{C}, \mathrm{M}, \mathrm{MB}$ & Percopo et al. 2013 \\
\hline Biecheleria cincta (Siano, Montresor \& Zingone) Siano & $\mathrm{C}, \mathrm{M}, \mathrm{MB}$ & Siano et al. 2009, Balzano et al. 2012 \\
\hline Prorocentrum nux Puigserver \& Zingone & $\mathrm{C}, \mathrm{M}$ & Puigserver and Zingone 2002 \\
\hline Protoperidinium parthenopes Zingone \& Montresor & M & Zingone and Montresor 1988 \\
\hline Protoperidinium vorax Siano \& Montresor & $\mathrm{C}, \mathrm{M}$ & Siano and Montresor 2005 \\
\hline Scrippsiella precaria Montresor \& Zingone & $\mathrm{C}, \mathrm{M}, \mathrm{RS}$ & Montresor and Zingone 1988 \\
\hline Scrippsiella ramonii Montresor & $\mathrm{C}, \mathrm{M}, \mathrm{RS}$ & Montresor 1995 \\
\hline \multicolumn{3}{|l|}{ Prasinophytes } \\
\hline Crustomastix stigmatica Zingone & $\mathrm{C}, \mathrm{M}, \mathrm{MB}$ & Zingone et al. 2002 \\
\hline Dolichomastix tenuilepis Throndsen \& Zingone & $\mathrm{C}, \mathrm{M}, \mathrm{MB}$ & Throndsen and Zingone 1997 \\
\hline \multicolumn{3}{|l|}{ Prymnesiophytes } \\
\hline Phaeocystis cordata Zingone \& Chrétiennot-Dinet & $\mathrm{C}, \mathrm{M}, \mathrm{MB}$ & Zingone et al. 1999a \\
\hline Phaeocystis jahnii Zingone & $\mathrm{C}, \mathrm{M}, \mathrm{MB}$ & Zingone et al. 1999a \\
\hline
\end{tabular}

*new genus

character, were initially based on morphology and ultrastructure (Table 2 and Fig. 5). Subsequently, the introduction of molecular methods has provided additional information that has robustly supported the establishment of new species and their correct attribution in cases of poor morphological characters, i.e. in flagellates. For example, without the support from molecular data, the tiny single cells flagellate Phaeocystis cordata Zingone \& Chrétiennot-Dinet (Fig. 5d) would have hardly been attributed to a genus that is mainly identified by its conspicuous colonial stages (Zingone et al. 1999a).

Successfully, taxonomic research at LTER-MC has retained a traditional morphological approach at the same time as embracing different aspects of the species identity, such as phylogeny (Kooistra et al. 2010, Gaonkar et al. 2018), life cycles (Levialdi Ghiron et al. 2008, Amato et al. 2005, D'Alelio et al. 2009b), mating compatibility with closely related species (Amato et al. 2007, D’Alelio et al. 2009a), biochemistry (Lamari et al. 2013, Nanjappa et al. 2014b), physiology and metabolomics (Degerlund et al. 2012, Huseby et al. 2012), feeding strategies (Modigh and Franzè 2009, Mahadik 2014), behavior (Bianco et al. 2013, Mahadik et al. 2017) as well as ecological aspects like species 


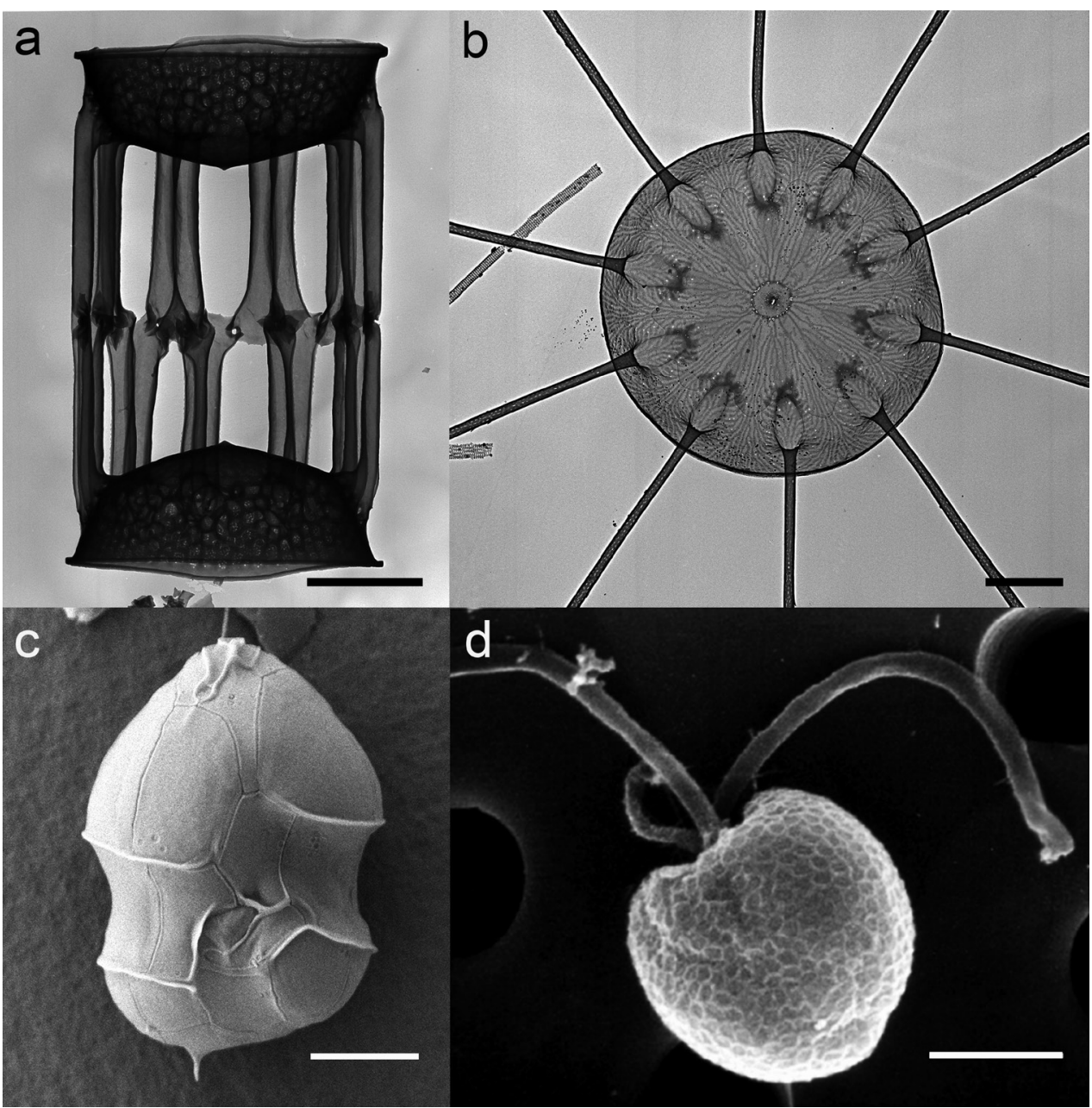

Figure 5. Some of the microalgal species discovered in the Gulf of Naples. a Skeletonema dohrnii Sarno \& Kooistra, a species very similar to S. marinoi Sarno \& Zingone, discovered instead in the Adriatic Sea. Both species bloom in late winter-early spring, whereas the most abundant species in the GoN, S. pseudocostatum, blooms in late spring b Bacteriastrum parallelum Sarno, Zingone \& Marino, a solitary diatom species in a genus entirely consisting of colonial species $\mathbf{c}$ Azadinium dexteroporum Percopo \& Zingone, a dinoflagellate producing several toxins of the group azaspiracids, and the first in this genus discovered in the Mediterranean Sea $\mathbf{d}$ Phaeocystis cordata Zingone \& Chrétiennot-Dinet, a prymensiophyte that differs from all the congeneric species because it apparently lacks a colonial stage.

diversity during blooms (Orsini et al. 2004) and phenology (Cerino et al. 2005, D’Alelio et al. 2010). It was precisely the latter trait, which can only be inferred from long-term observations, that draw attention to certain taxa, e.g., 'Skeletonema costatum (Greville) Cleve' showing different seasonality between the Tyrrhenian and Adriatic seas, or 'Leptocylindrus danicus Cleve' occurring all year round in the GoN. These phenological peculiarities inspired detailed studies on these previously ill-defined taxa, with relevant insights 
into their actual diversity and the seasonal occurrence of the redefined species, which demonstrate the reciprocal advantages of taxonomic and ecological studies conducted at the same place. Over the years, this cutting edge approach to taxonomy has resulted in pioneering researches that have soundly demonstrated cryptic and pseudo-cryptic diversity as common features in microbes. Results obtained on iconic phytoplankton species such as the dinoflagellate Scrippsiella (D'Onofrio et al. 1999, Montresor et al. 2003) and the diatoms Pseudo-nitzschia (Amato et al. 2007, Amato and Montresor 2008), Skeletonema (Zingone et al. 2005, Sarno et al. 2005, 2007) and Leptocylindrus (Nanjappa et al. 2013) have definitely challenged some common paradigms on marine microbes. For example, the idea that they are ubiquitous and opportunistic, being able to thrive in any place (e.g., Finlay 2002), has been contrasted by the first evidences of clearly distinct temporal and phylogeographic patterns (Kooistra et al. 2008, Nanjappa et al. 2013, Ruggiero et al. 2015), subsequently confirmed also for cryptic species with HTSmetabarcoding investigations (Nanjappa et al. 2014a, Gaonkar 2016, Pargana 2017).

The description of diversity has been further deepened at the population level in the case of the diatom Pseudo-nitzschia multistriata (Takano) Takano, selected as a model, which was found to consist of genetically distinct populations (Fig. 6) in samples collected at LTER-MC over four consecutive years (Tesson et al. 2014). This result, further confirmed in two subsequent years (Ruggiero et al. 2018), has been interpreted as the outcome of genetic recombination regularly occurring in this species (D'Alelio et al. 2009a, 2010) coupled with the rapid diversification during vegetative growth (Tesson et al. 2013). Interestingly, during the autumn bloom in 2013, a 'clonal expansion' event took place, with the sudden increase of diversification by mutation and the subsequent dominance of a single genotype. The availability of genomic resources for P. multistriata will allow deeper investigations into the dynamics of evolutionary adaptation to changing environmental conditions in the GoN.

Accurate data on species diversity gathered at the LTER-MC site have also enabled the discovery of a number of potential Invasive Alien Species (IAS). The definition and detection of IAS in plankton organisms are particularly tricky and biased by several factors, such as difficult identification, spatial patchiness and ephemeral occurrence. All these problems can be partially overcome in places where plankton species are properly identified over a long-term period. At the LTER-MC station, at least two diatom species, Pseudo-nitzschia multistriata and Skeletonema tropicum Cleve, were never recorded until 1995 and 2002, respectively, despite their relatively easy identification (Zingone et al. 2003, Zenetos et al. 2010, Corriero et al. 2016,) and the non-indigenous calanoid copepod Pseudodiaptomus marinus Sato, 1913 (Sabia et al. 2015) has suddenly appeared in recent years. Interestingly, at least one case of local extinction has also occurred with Pseudo-nitzschia subpacifica (Hasle) Hasle, never retrieved in the area as of 1988 (Zingone et al. 2003).

Considering the possible impact of potentially toxic and harmful species in such a densely populated area as the GoN, the high attention paid to the taxonomy and distribution of these species in the area is not surprising. A more detailed description and a sound taxonomic assessment have been provided for several harmful diatom 


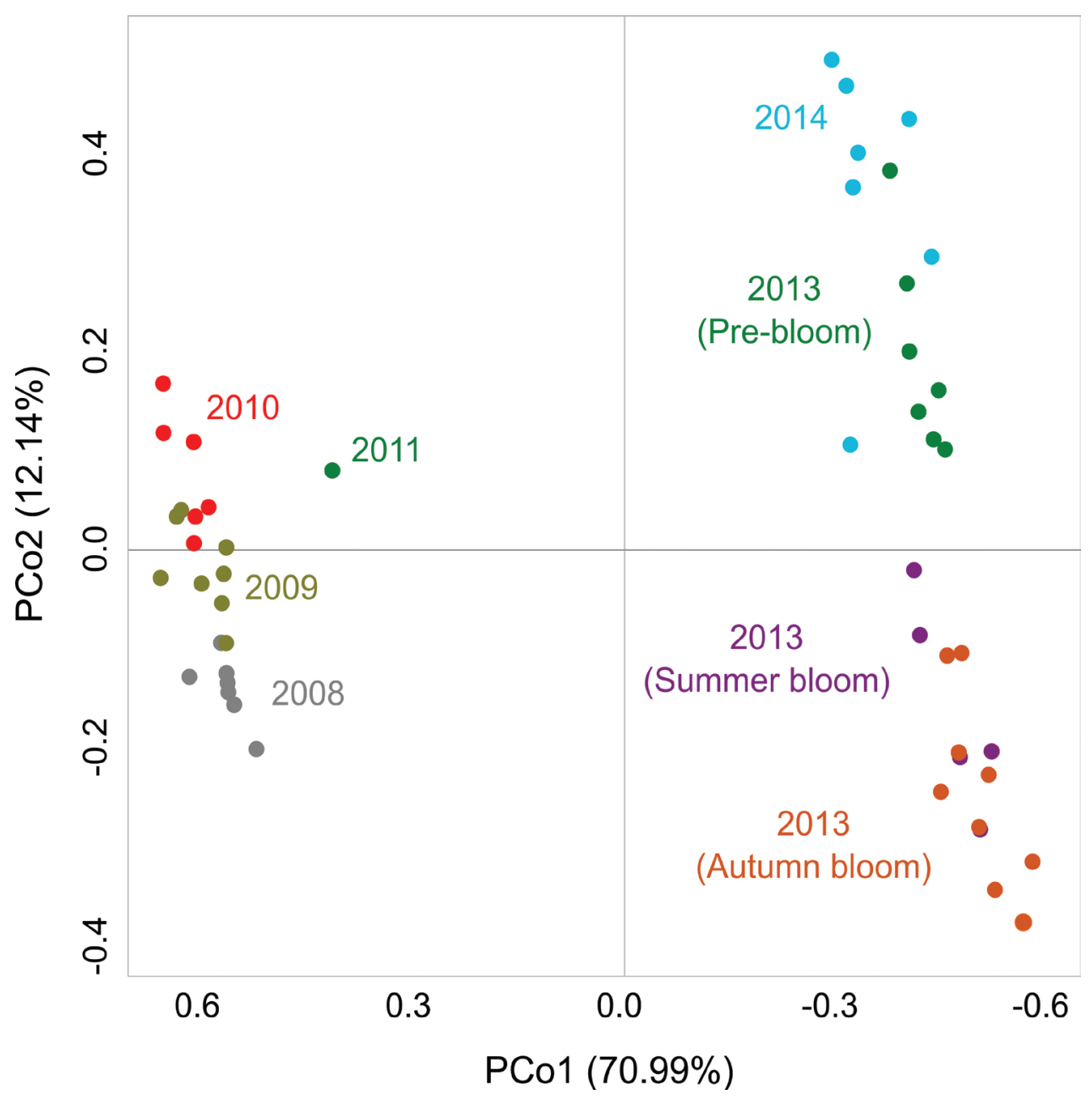

Figure 6. Different Pseudo-nitzschia multistriata populations, identified by microsatellite marker analysis, succeeding one to the other at station LTER-MC from 2008 to 2014. Redrawn from Ruggiero et al. (2018).

(e.g., Orsini et al. 2002, Cerino et al. 2005) and dinoflagellate species (e.g., Zingone et al. 1998, Escalera et al. 2014, 2018). In many cases, non-toxic species have been discovered in the GoN which only show subtle morphological differences from the toxic congeneric ones, as in the case of the dinoflagellates Alexandrium tamutum Montresor, Beran \& U. John, similar to the toxic $A$. minutum Halim (Montresor et al. 2004), and $A$. mediterraneum $\mathrm{U}$. John (group II), similar to the toxic A. catenella (Whedon \& Kofoid) Balech (group I) and A. pacificum Litaker (group IV) (John et al. 2014), and the diatom Pseudo-nitzschia mannii Amato \& Montresor, hardly distinguishable from the toxic P. calliantha Lundholm, Moestrup \& Hasle (Amato and Montresor 2008). Recently, the first Mediterranean species of the dinoflagellate genus Azadinium, A. dexteroporum Percopo \& Zingone (Fig. 5c), has been discovered in the GoN (Percopo et al. 2013), 
along with a suite of new, probably toxic azaspiracids that it produces (Rossi et al. 2017). Overall, about 50 toxic and/or potentially harmful species have been detected over the years in the area, where the time series and additional sampling have contributed relevant data on their distribution and seasonality (Zingone et al. 2006b and unpublished data). This precious information can help with identifying periods of the year of higher risk of toxic species occurrence, providing guidance to informed monitoring and contributing to improve the management of toxicity outburst and the protection of food security.

\section{Molecular diversity: the metabarcoding approach}

The detection and quantification of species that are difficult to identify with morphology-based methods have been a goal for many years at LTER-MC, where a number of different attempts have been made to introduce adequate methods (McDonald et al. 2007a, b, Barra et al. 2013, Santamaria et al. 2015, McNamee et al. 2016). The direct access to molecules that are diagnostic for the individual taxa has opened a whole new range of possibilities for the study of microbial life, which has been scarcely known hitherto because of incomplete sampling, difficult cultivation and inadequate identification tools. To obtain the whole list of species from a single sample has been a long held dream that has now come true with the introduction of metabarcoding. The first and most comprehensive experiments using this approach have concerned sampling cruises at a local and worldwide scale (e.g. Moon-Van der Staay et al. 2001, de Vargas et al. 2015). Yet it has soon been acknowledged that the use of this new powerful tool is maximized at places with a sound background knowledge of the system, which allows for taking full advantage of the new information by integrating it with that deriving from classical methods (Davies et al. 2014, Stern et al. 2018).

Metabarcoding studies at the LTER-MC site started soon when the new molecular technologies became available to marine research. First tests demonstrated the potential of metabarcoding to overcome the two most arduous obstacles in diversity studies, i.e., the bad identification of species hardly seen in fixed material (e.g., tiny flagellates) and the difficulty to trace cryptic species in the environment. A great diversity and abundance of Prymnesiophyceae, until that time uncovered, was highlighted for the first time at LTER-MC in a study using dot blots and clone libraries (McDonald et al. 2007a), which also confirmed results on the seasonality of several cryptophyte species obtained with culturing methods (Cerino and Zingone 2006). In addition, hardly distinguishable, toxic and non-toxic species of the diatom genus Pseudo-nitzschia were first identified using PCR on environmental DNA samples with genus-specific LSU rDNA primers, followed by cloning (McDonald et al. 2007b). The latter experiment confirmed the idea, initially proposed based on strain isolation and culturing, that during seasonal blooms several almost identical congeneric species may coexist (Orsini et al. 2004). Subsequently the whole annual cycle of Pseudo-nitzschia species was reconstructed with the same approach, highlighting the high diversity of this genus and the different seasonality of the apparently alike species that belong to it (Ruggiero et al. 
2015). In all these cases, the samples to submit to molecular analysis were selected based on the knowledge of the seasonal occurrence of flagellates and Pseudo-nitzschia acquired in years of morphology-based investigations, while the interpretation of the results was robustly supported by the comparison between molecular and light-microscopy results from the same samples, thus definitely proving that genomic observatories do benefit from background and contextual knowledge obtained with classical methods.

The huge diversity of prymnesiophytes in the plankton was subsequently confirmed by the first metabarcoding study in the GoN that used High Throughput Sequencing (HTS) on protist amplicons obtained with specific haptophyte primers, in the frame of the EU project BioMarKs (Bittner et al. 2013). Within the same project, the LTER-MC station was compared with five other European sites addressing the distribution of protists in coastal waters (Massana et al. 2015), rare species (Logares et al. 2014), the sediment assemblages (Forster et al. 2016) and the diatom community (Piredda et al. 2018).

Temporal changes in planktonic protist compositions at LTER-MC were investigated in a dedicated metabarcoding study carried out on eight sampling events over one year (Fig. 7, Piredda et al. 2017b). The presence of about 6,000 OTUs, many of which not attributable to any known protist genus, in such a limited number of samples, pointed to the high and largely unexplored diversity of the marine microbial world, at the same time revealing high variations of their diversity across the seasons, with a maximum in winter. Also in this case a correspondence was highlighted with samples analyzed with classical methods focusing on diatoms, for which the most complete datasets exist for both reference sequences and morphological identification. Metabarcoding analyses were also successfully applied to diatom resting stages, obtaining a quite complete picture of the diversity of the seed bank in the LTER-MC sediments (Piredda et al. 2017a).

The implementation of molecular studies in long term plankton observatories is nowadays occurring at several places, with slightly different approaches and methods (Stern et al. 2018) that need to be harmonized to allow for full intercomparability of the results. In this respect, the experience and knowledge gained at the LTER-MC site represent a useful contribution to the development of appropriate methodologies as well as a convincing example of the value of introducing such molecular approaches in classic, morphology-based ecological research on plankton organisms.

\section{Life cycles}

The LTER-MC time series has offered the precious opportunity not only to deepen the knowledge on plankton diversity but also to shed light on different phases in the life cycles of individual species, such as the many developmental stages of copepods or the benthic stages of many planktonic protists. Understanding the structure of species life cycles, along with the external (environmental) or internal (biological) cues that determine life-stage shifts and impact their viability, provides a framework to interpret the success and occurrence of the species across the seasons and the way they interact with the environment and with other organisms. 


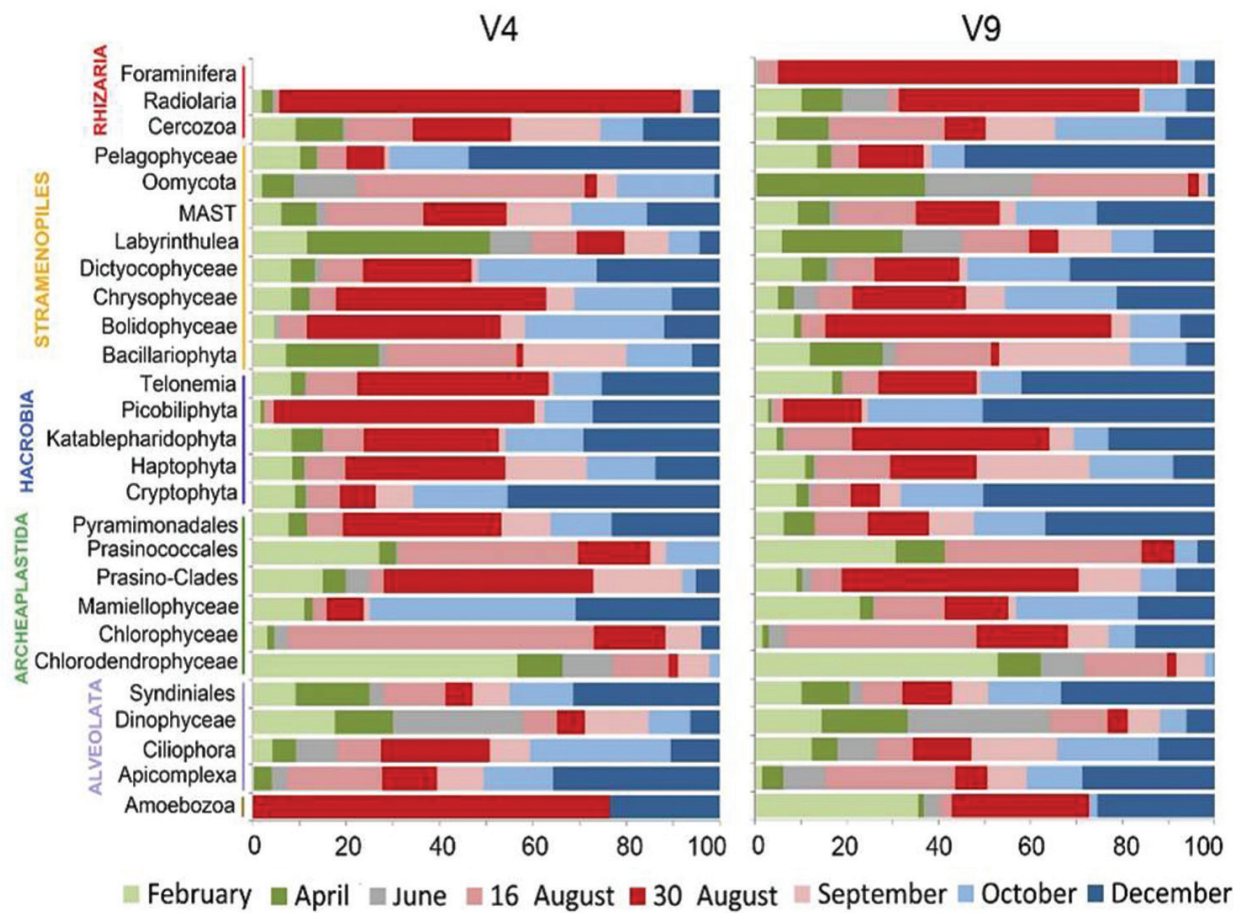

Figure 7. Protist seasonality at station LTER-MC, as revealed by the relative abundance of reads obtained by High Throughput Sequencing (HTS)-metabarcoding using two different $18 \mathrm{~S}$ rDNA sequence fragment, V4 and V9. For each protist group, read abundance on different sampling dates was normalized over the total abundance of that group, in order to show the marked differences in seasonal patterns among groups. With the exception of a few cases, V4 and V9 gave similar results. From Piredda et al. (2017b), by permission of Oxford University Press.

For plants and metazoans, life cycle is defined as a series of changes and developmental stages that an organism passes through from the beginning of its life until its death. In protists, different stages correspond to distinct forms in which cells of a species exist in the environment, which may exhibit different morphologies, perform in different ways and follow a different destiny (von Dassow and Montresor 2011). The capability to enter a resting phase is probably the aspect of the life cycle of planktonic unicellular organisms that has attracted the most attention. Resting stages have a different morphology and/or physiology as compared to the vegetative cells that grow in the water column. Resting stages can survive in the sediments for many years, thus constituting a sort of 'seed bank' of diversity which, upon germination, inoculates the water column with vegetative cells. In the GoN, 59 dinoflagellate cyst morphotypes (less than $20 \%$ of the dinoflagellate species found in the plankton) were recorded in surface sediments and sediment traps (Montresor et al. 1998), with high production rates (up to $1.7 \times 10^{5}$ cysts $\mathrm{m}^{-2} \mathrm{day}^{-1}$ ) and rather similar species composition over two years investigated (Fig. 8a). The cyst assemblage was dominated by calcareous cysts of 
Scrippsiella species and small organic-walled cysts produced by unarmoured dinoflagellates. The abundance of viable diatom resting stages in sediments from LTER-MC was instead estimated with the Most Probable Number method applied to Serial Dilution Cultures (MPN-SDC), because their small size prevents their direct observation in the sediments. On eight sampling dates spanning over a year-and-a-half, 30 diatom species (ca 1/3 of those recorded in the plankton) were obtained from sediment germination (Montresor et al. 2013), of which the most abundant were Skeletonema pseudocostatum, Leptocylindrus danicus, Chaetoceros socialis (Fig. 8b) and other Thalassiosirales. A pilot experiment comparing the results of the MPN-SDC and the HTS-metabarcoding approaches demonstrated a good match between the two methods (Piredda et al. 2017a).

Another crucial phase of protist life cycle is sexual reproduction which, besides its importance for genetic recombination (for the Pseudo-nitzschia genus, see D'Alelio and Ruggiero 2015 and Ruggiero et al. 2018), in diatoms produces large sized cells that counteract the progressive cell miniaturization that features their vegetative phase (Montresor et al. 2016). In the laboratory, basic information was obtained on sexual reproduction of selected Pseudo-nitzschia species from LTER-MC (Amato et al. 2005, Amato and Montresor 2008, D'Alelio et al. 2009b). These potentially toxic species have become models for several studies partly because they are heterothallic, i.e., sex can only occur when cells of opposite mating type are co-cultured, which has also allowed for testing the biological species concept and elucidating the actual diversity among cryptic or pseudo-cryptic species (Amato et al. 2007).

At LTER-MC, one of the few massive sex events ever recorded for diatoms in the natural environment has taken place, whereby two different species, $P$. cf. delicatissima and $P$. cf. calliantha, were found to undergo sex at the same time (Sarno et al. 2010). The ephemeral nature of these events may explain why such reports are so scanty, but cell-size variations and the presence of large-sized cells formed following sexual reproduction can provide an indirect way to infer the occurrence of diatom sex in the natural environment. Indeed, records of $P$. multistriata cell-size in plankton samples from LTER-MC over ten years, coupled with a modelling approach, showed that this species undergoes sex every two years (D'Alelio et al. 2010), which to date represents the only indication of an internal clock that rules the occurrence of sex and the shift of growth phase across the seasons in diatoms. More sophisticated tools are offered today by genes expressed during sexual reproduction, first identified in some diatom species from LTER-MC (Patil et al. 2015, Basu et al. 2017, Nanjappa et al. 2017), which can be searched in protist meta-transcriptomes, with a great potential to shed light on the actual occurrence of sexual events in the natural environment.

Life history traits in zooplankton at station LTER-MC have been analysed in conspicuous copepod species, such as Acartia clausi, Centropages typicus and Temora stylifera, with particular focus on reproduction and development. Results of experimental and in situ studies on egg production, hatching success, survival and temporal distribution of naupliar and copepodite stages showed remarkable differences among species that highlight the characteristic strategies of species co-occurring in temperate areas (e.g., Ianora and Buttino 1990, Ianora 1998, Di Capua and Mazzocchi 2004, Carotenuto et al. 2006). In $C$. typicus and $A$. clausi, the highest egg production rates were 
(a)

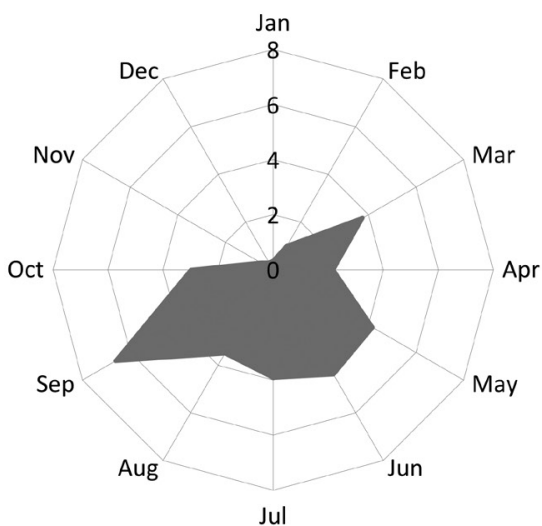

(b)

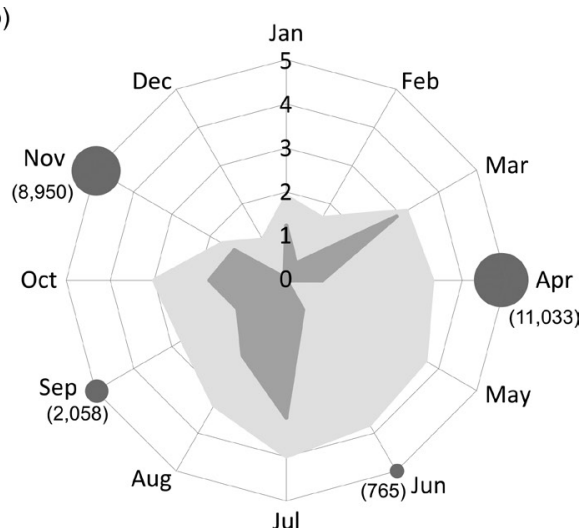

Figure 8. Phytoplankton resting stages at station LTER-MC. a Dinoflagellate cyst fluxes (cysts $\times 10^{5} \mathrm{~m}^{-2}$ $\mathrm{d}^{-1}$ ); average monthly values over two years (1994 and 1995) (data from Montresor et al. 1998) b abundance of spores of Chaetoceros socialis (circles, viable spores $\times 10^{3} \mathrm{~g}^{-1}$ of wet sediment) in April, June, September and November, and average monthly cell abundance $\left(\log 10(\mathrm{n}+1) \mathrm{ml}^{-1}\right)$ of spore-forming diatoms (light gray polygon) and of $C$. socialis in the plankton (dark gray polygon) (data from Montresor et al. 2013).

recorded at relatively low female abundance and viceversa suggesting that copepods invest resources towards reproduction only in specific periods of their annual cycle, independently from the number of females in the population (Ianora and Buttino 1990, Ianora et al. 1992). However, Ianora and Poulet (1993) provided the first evidence that egg hatching success is also linked to food quality, with egg production and viability benefiting from a dinoflagellate diet and being impaired by a diatom diet. These results set the ground for a series of studies showing that some diatom species produce secondary metabolites (PUA and various oxylipins) that affect hatching success and naupliar viability (Ianora and Miralto 2010). The crucial role of food quality but also of different mortality rates of the various developmental stages in shaping population dynamics was proven by a Lagrangian individual-based model run with data of $T$. stylifera populations at LTER-MC (Mazzocchi et al. 2006). Indeed mortality, by both natural causes and predation, is a fundamental process that affects zooplankton population dynamics. As an example, the average percentage of carcasses at LTER-MC has been estimated to be around $10 \%$ of the total copepod population, with juveniles always more vulnerable as compared to adults (Di Capua and Mazzocchi 2017).

Overall these studies, along with similar ones from other areas (e.g., Johnson et al. 2008, Renz and Hirche 2006), highlight the importance of knowing population demography for different species in order to better understand the variability in structure and temporal course of zooplankton at sea. Significant long-term trends of zooplankton populations have been observed around the world (Harris et al. 2014) and some evidence of declines is appearing also in the GoN (M.G. Mazzocchi, I. Di Capua and I. Carotenuto unpublished data), which should be elucidated by tracing the environmental changes that may have occurred in critical periods of the year, thus affecting specific life cycle phases of individual species. This is very relevant also for the possible repercussions on the trophic web structure and the productivity of the sea. 


\section{Biological interactions}

In addition to endogenous rhythms dictated by life cycles and exogenous environmental forcing, the occurrence and seasonality of plankton species can be determined or modulated by positive or negative interactions with other co-occurring organisms. One such obvious case is represented by trophic relationships, which have received much attention since the first studies on plankton ecology and have started to be investigated at LTER-MC as well.

Plankton communities are complex ensembles of unicellular organisms with different metabolism types, from strictly photoautotrophic to phagotrophic and mixotrophic (i.e., microzooplankton or protozooplankton), which can shift between heterotrophy and autotrophy, and multicellular organisms with distinct diets, from predominant herbivory to omnivory or strict carnivory: plankton organisms therefore can display multiple trophic interactions, which result in complex food-webs (e.g., D'Alelio et al. 2016b). Grazing experiments in the GoN involving the lower levels of the plankton food-web, namely phyto- and microzooplankton, have revealed: i) a seasonality in the consumption of phytoplankton by microzooplankton, with higher rates during winter compared to spring and summer (> -30\%) (Modigh and Franzè 2009); and ii) a strong 'cannibalism' among heterotrophic protists, with up to $78 \%$ of microzooplankton production not exported to higher trophic levels but consumed within microbial trophicloops (Franzè and Modigh 2013). Furthermore, grazing experiments with diatoms suggested that copepods from LTER-MC, despite size- selectivity, display a predominantly generalist and plastic trophic behavior (Mahadik 2014, Mahadik et al. 2017).

The multiple and flexible trophic interactions occurring within plankton have recently been explored taking advantage of the detailed information on species that occupy different trophic levels and using LTER-MC as a model system for developing conceptual and computational models of the plankton food web. A first model (D'Alelio et al. 2015) has targeted the whole plankton community during the summer season in the years 2002-2009, from nanoflagellates to predatory mesozooplankton (individual size spanning from $5 \mu \mathrm{m}$ to $2 \times 10^{3} \mu \mathrm{m}$ ). Co-variations of species trends were used as evidence of the different trophic links, which were assembled into networks that were investigated in order to identify the response of the system as a whole to different trophic conditions (e.g., Loreau 2010). Besides a well-resolved reconstruction of the web of trophic interactions, it has been possible to test the response of this web to short-term physical-chemical variability typical of the coastal GoN (Ribera d'Alcalà et al. 2004, Cianelli et al. 2017). The trophic network (Fig. 9) was dominated by links connecting phytoplankton and mesozooplankton during coastal, eutrophic states and by microbial loops during offshore, oligotrophic states (D'Alelio et al. 2015). Other interesting characteristics of the GoN plankton food web were that: i) the resource intermittency may propagate from individuals to individuals' interactions; ii) the community may respond 'adaptively' to oscillations between eu- and oligotrophy; and iii) biological diversity seems to be the main driver of this latter system response.

Building on this conceptual model, a food-web computational model was subsequently developed and fed with data of carbon biomass fluxes derived from LTER-MC 


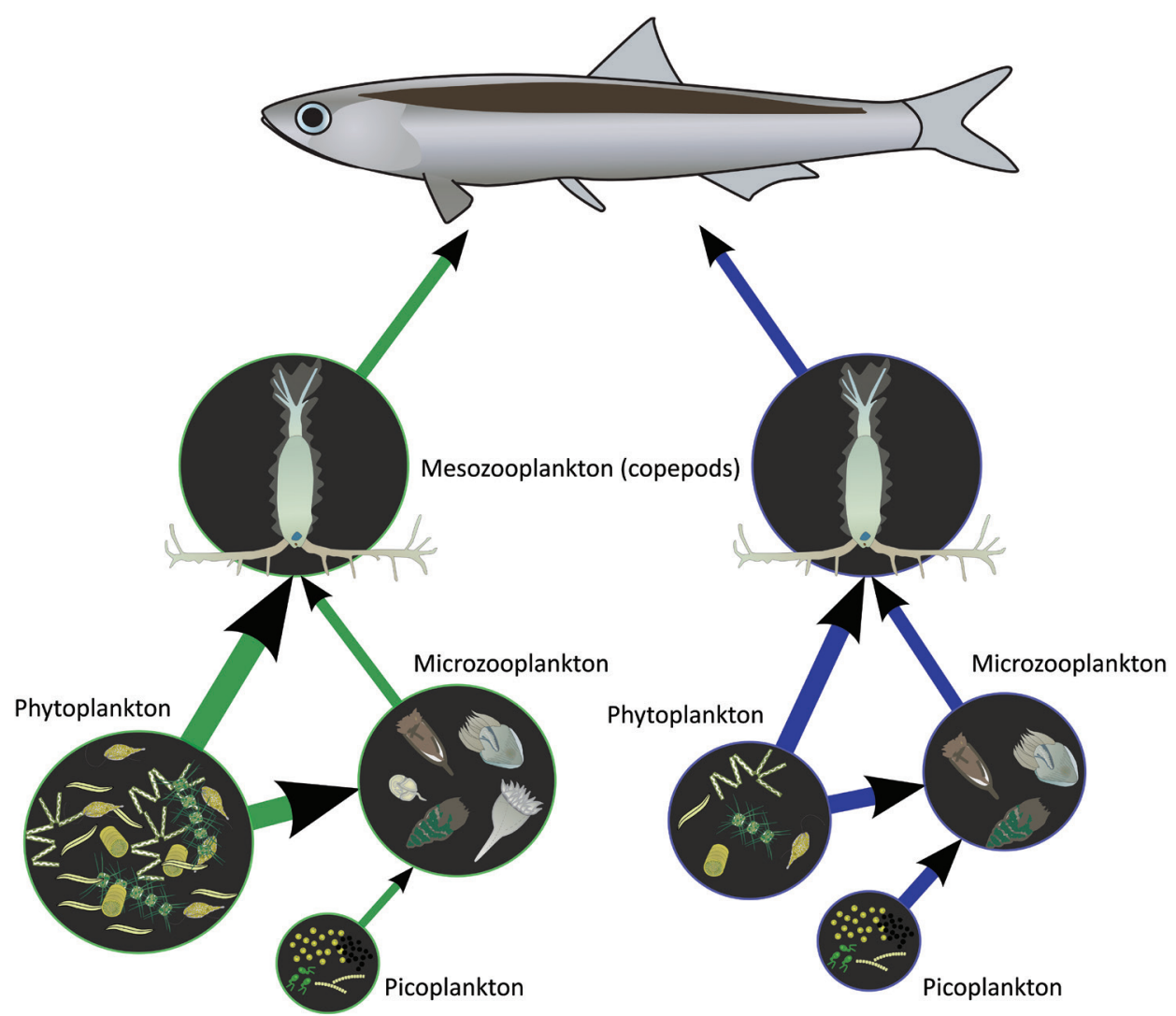

Figure 9. A simplified version of a food web in the Gulf of Naples in eutrophic (Green) and oligotrophic (Blue) summer conditions, modified from D'Alelio et al. (2016a). Briefly, in the Green system state, both copepods and microzooplankton exert a strong grazing pressure on phytoplankton, while in the Blue state, copepods increase their predation over microzooplankton, which in turn shifts its predation from phytoplankton to bacterial plankton or picoplankton. These trophic mechanisms stabilize the delivery of organic matter from copepods to fish.

studies, complemented with available knowledge concerning the biological characteristics of plankton organisms from the GoN (D'Alelio et al. 2016a, b). The model built by exploiting the Ecopath methodology allowed for reconciling, within a single network framework, three important ecosystem properties: how many species are there (community biodiversity), how these relate reciprocally (community structure) and what they do collectively (community functioning) (Thompson et al. 2012). The Ecopath model indicates that almost all consumers in the plankton food-web are capable of switching trophic preferences based on available resources, i.e., when the system shifts between eu- and oligotrophic states, and it also suggests the ecological importance of neglected biological processes, such as mixotrophy and differentially selective feeding by micro- and mesozooplankton. These characteristics expand the hyperspace of potential- 


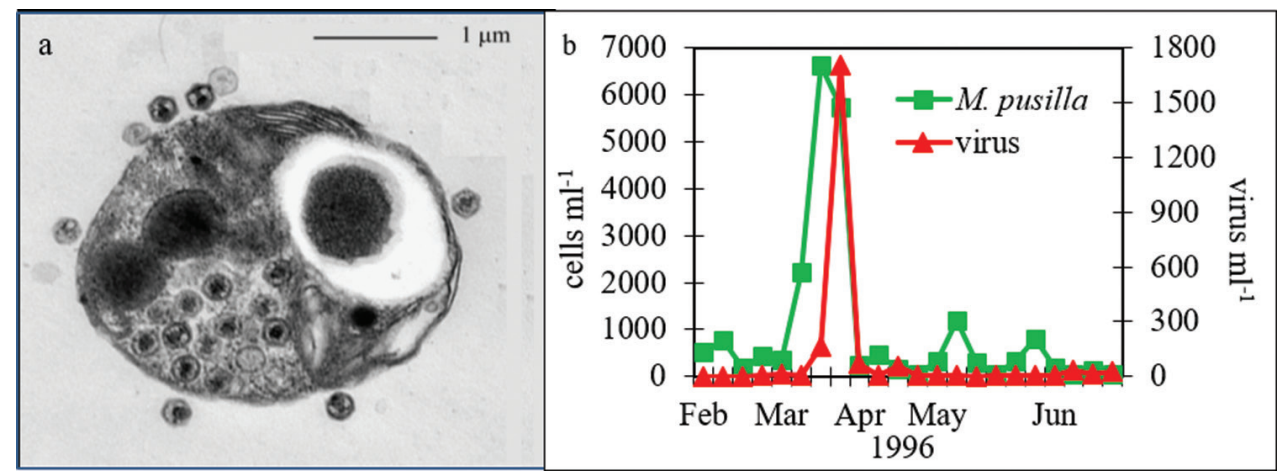

Figure 10. Viral infection in the prasinophyte Micromonas pusilla. a Transmission electron micrograph of an infected cell $\mathbf{b}$ abundance of the virus and its host at station LTER-MC in spring 1996 (data from Zingone et al. 1999b). In the following two years the seasonal trend of host and virus appeared to be less coupled, which pointed to complex relationships between different viral and host strains.

ly available trophic pathways, thus conferring the protozoan-metazoan links the highest trophic efficiency (i.e., the highest ratio between the biomass taken up by a trophic level and that delivered by the same trophic level to the subsequent one). This high efficiency allows dampening the negative effect of the decrease in primary production on planktivorous fish production at the oligotrophic system state. Specifically, when phytoplankton biomass was seven-fold lower than at the eutrophic state, calanoid copepods significantly increased their grazing pressure on protozooplankton, which, in turn, increased their pressure on picophytoplankton, less consumed by calanoids because of their small cell size. Instead the food-web was highly dissipative at the lowest trophic levels, i.e., at phytoplankton-protozooplankton trophic step: the matter and energy not delivered at the higher level of the web was apparently used by protozooplankton as a resource to maintain species survival and, thus, the diversity of unicellular heterotrophs.

Unlike trophic relationships, other forms of interactions among organisms in the plankton have received less attention until recently. For example, the impact of viruses on the dynamics of planktonic populations is still hardly known and few are the species for which viruses have been identified. One such case is Micromonas pusilla (Butcher) Manton et Parke, a small prasinophycean flagellate abundant at LTER-MC from autumn to early spring. Viruses specific for this species (Fig. 10a) were recorded all over the period in which the host was present at sea, along with a great intraspecific variability in host susceptibility to the viruses (Zingone et al. 1999b). In some cases, peaks of the host were accompanied by an increase in viral concentrations, showing that viruses were responsible for algal mortality (Fig. 10b). However, based on results of three consecutive years, there was no evidence that viruses were able to terminate the host bloom. In fact, viral strains isolated from the GoN showed differences in infection capability when tested on strains of $M$. pusilla from the same area and from different geographic sites (Zingone et al. 2006a). In addition, host cultures generally recovered after the infection and became resistant to infection from the same virus. These results highlight 
the complex dynamics of algal-virus interactions, where diversity in viral infection capability, coupled with differences in intraspecific susceptibility of the host and differences in acquired resistance to the viruses, interplay to generate a sort of equilibrium.

Parasites also represent a poorly known loss factor in planktonic population $\mathrm{dy-}$ namics. The limited information available at LTER-MC was obtained for the copepod Paracalanus parvus where females and juveniles were parasitized by dinoflagellates (Ianora et al. 1987, 1990). Infections by Syndinium were greatest in juveniles (up to $30 \%)$ than in adult females (8\%) and completely absent in males. The identification of parasites in unicellular organisms is challenging, but HTS-based metabarcoding approaches are now available and showed that Syndiniales can be relatively abundant components of the protist community (Piredda et al. 2017b).

\section{Conclusions and future perspectives}

More than three decades of studies at station LTER-MC in the Gulf of Naples have definitely proved the relevance and potentiality of this research site as a precious asset not only to trace plankton changes at different scales and under different environmental conditions but also as a natural laboratory and a source of inspiration for complementary scientific research that has widened substantially our knowledge of the planktonic organisms and of the system as a whole.

As typical for coastal areas, the temporal course of the water column environment has shown to be remarkably variable throughout the years. Nevertheless, a notable resilience has characterized the plankton assemblages both in their bulk properties and at the level of individual species, with repeated seasonal patterns pointing to some biological and functional adaptability. These properties are also featured in the flexible organization of the food web under different hydrographic conditions, which points to a behavioral plasticity of individual species, as also disclosed by targeted experimental studies. Still the trends that have been recorded for temperature, chlorophyll and phytoplankton size, and the significant changes recorded in the abundance and phenology of some species need to be investigated in depth in their role of possible sentinel of environmental changes.

A fraction of the hidden marine diversity has been uncovered with the description of a high number of phytoplankton species and the elucidation of crypticity, which have greatly improved the capability to interpret seasonal and biogeographical patterns so far blurred by the misidentification of the significant taxonomic units. These results support the consideration that precision in taxonomic identification is a requisite of ecological studies, and in many cases higher taxa (e.g., genera or classes) include too much diversity to be ecologically meaningful. Further, placing specific, intraspecific and population variability in the frame of natural environmental variability has proven to be a good opportunity to shed light on both the ecological meaning and the evolutionary potential of diversity. High diversity in planktonic elements has also emerged from the analysis of small-scale behavior and life-history traits such as development, reproduction and dormancy, as well as natural and pathological mortality. Overall, 
the results of these studies highlight the fundamental role of biological processes and individual performances in the coexistence and/or succession and phenological characterization of the species, beyond the influence of environmental conditions.

In spite of the quite wide-ranging results obtained so far, much remains to be done in terms of exploring and filling the knowledge gaps emerging from them and gaining further comprehension of the planktonic system. In addition to in-depth studies on the data set and complementary research in line with what has been done so far, the complexity of plankton diversity and dynamics prompts us to further extend and intensify our efforts using novel approaches. To this end, an augmented marine observatory is being established which couples traditional and -omics approaches applied at the fixed LTER-MC and periodically over a larger spatial grid. In addition, sustained recording by means of fixed mooring bearing optical and acoustic sensors and biomolecular samplers is planned to complement the traditional data gathering procedure. The augmented observatory is aimed at a complete characterization of plankton communities (meta-barcoding and meta-genomics) and of their functions (meta-transcriptomics) through the analysis of barcodes, complete gene sets and their expression patterns. This empowerment of the LTER-MC research activities will also allow investigating other planktonic taxa neglected so far (e.g., jellyfish and fish larvae) and including further trophic links into pre-existing ecological networks and will likely shed further light on the processes underlying the extraordinary plankton world.

\section{Acknowledgements}

The LTER-MC team includes, besides the main authors: C. Balestra, M. Cannavacciuolo, R. Casotti, F. Conversano, I. Di Capua, D. Iudicone, F. Margiotta, A. Passarelli, I. Percopo, M. Ribera d'Alcalà, M. Saggiomo, V. Saggiomo, F. Tramontano, G. Zazo, all based at Stazione Zoologica Anton Dohrn of Naples. The research program LTERMC is supported by the Stazione Zoologica Anton Dohrn. DDA has been funded by the Flagship Project RITMARE - The Italian Research for the Sea - funded by the Italian Ministry of Education, University, and Research within the National Research Program 2011-2013.

\section{References}

Amato A, Montresor M (2008) Morphology, phylogeny, and sexual cycle of Pseudo-nitzschia mannii sp. nov. (Bacillariophyceae): A pseudo-cryptic species within the P. pseudodelicatissima complex. Phycologia 47(5): 487-497. https://doi.org/10.2216/07-92.1

Amato A, Orsini L, D'Alelio D, Montresor M (2005) Life cycle, size reduction patterns, and ultrastructure of the pennate planktonic diatom Pseudo-nitzschia delicatissima (Bacillariophyceae). Journal of Phycology 41(3): 542-556. https://doi.org/10.1111/j.15298817.2005.00080.x 
Amato A, Kooistra WHCF, Levialdi Ghiron JH, Mann DG, Pröschold T, Montresor M (2007) Reproductive isolation among sympatric cryptic species in marine diatoms. Protist 158(2): 193-207. https://doi.org/10.1016/j.protis.2006.10.001

Balzano S, Gourvil P, Siano R, Chanoine M, Marie D, Lessard S, Sarno D, Vaulot D (2012) Diversity of cultured photosynthetic flagellates in the northeast Pacific and Arctic Oceans in summer. Biogeosciences 9(11): 4553-4571. https://doi.org/10.5194/bg-9-4553-2012

Barra L, Ruggiero MV, Sarno D, Montresor M, Kooistra WCHF (2013) Strengths and weaknesses of microarray approaches to detect Pseudo-nitzschia species in the field. Environmental Science and Pollution Research International 20(10): 6705-6718. https://doi. org/10.1007/s11356-012-1330-1

Basu S, Patil S, Mapleson D, Russo MT, Vitale L, Fevola C, Maumus F, Casotti R, Mock T, Caccamo M, Montresor M, Sanges R, Ferrante MI (2017) Finding a partner in the ocean: Molecular and evolutionary bases of the response to sexual cues in a planktonic diatom. The New Phytologist 215(1): 140-156. https://doi.org/10.1111/nph.14557

Beaugrand G (2004) The North Sea regime shift: Evidence, causes, mechanisms and consequences. Progress in Oceanography 60(2-4): 245-262. https://doi.org/10.1016/j. pocean.2004.02.018

Berline L, Siokou-Frangou L, Marasovic I, Vidjak O, de Puelles MLF, Mazzocchi MG, Assimakopoulou G, Zervoudaki S, Fonda-Umani S, Conversi A, Garcia-Comas C, Ibanez F, Gasparini S, Stemmann L, Gorsky G (2012) Intercomparison of six Mediterranean zooplankton time series. Progress in Oceanography 97: 76-91. https://doi.org/10.1016/j. pocean.2011.11.011

Bianco G, Botte V, Dubroca L, Ribera d'Alcalà M, Mazzocchi MG (2013) Unexpected regularity in swimming behavior of Clausocalanus furcatus revealed by a telecentric 3D computer vision system. PLoS One 8(6): e67640. https://doi.org/10.1371/journal.pone.0067640

Bittner L, Gobet A, Audic S, Romac S, Egge ES, Santini S, Ogata H, Probert I, Edvardsen B, De Vargas C (2013) Diversity patterns of uncultured Haptophytes unravelled by pyrosequencing in Naples Bay. Molecular Ecology 22(1): 87-101. https://doi.org/10.1111/mec.12108

Carotenuto Y, Ianora A, Di Pinto M, Sarno D, Miralto A (2006) Annual cycle of early developmental stage survival and recruitment in the copepods Temora stylifera and Centropages typicus. Marine Ecology Progress Series 314: 227-238. https://doi.org/10.3354/meps314227

Carrada GC, Fresi E, Marino D, Modigh M, Ribera d'Alcalà M (1981) Structural analysis of winter phytoplankton in the Gulf of Naples. Journal of Plankton Research 3(2): 291-314. https://doi.org/10.1093/plankt/3.2.291

Carrada GC, Hopkins TS, Bonaduce G, Ianora A, Marino D, Modigh M, Ribera d'Alcalà M, Scotto di Carlo B (1982) Variability in the hydrographic and biological features of the Gulf of Naples. PSZN Marine Ecology 1(2): 105-120. https://doi.org/10.1111/j.1439-0485.1980.tb00213.x

Castellani C, Licandro P, Fileman E, Di Capua I, Mazzocchi MG (2015) Oithona similis likes it cool: Evidence from two long-term time series. Journal of Plankton Research 38(3): 703-717. https://doi.org/10.1093/plankt/fbv104

Cerino F, Zingone A (2006) A survey of cryptomonad diversity and seasonality at a coastal Mediterranean site. European Journal of Phycology 41(4): 363-378. https://doi. org/10.1080/09670260600839450 
Cerino F, Orsini L, Sarno D, Dell'Aversano C, Tartaglione L, Zingone A (2005) The alternation of different morphotypes in the seasonal cycle of the toxic diatom Pseudo-nitzschia galaxiae. Harmful Algae 4(1): 33-48. https://doi.org/10.1016/j.hal.2003.10.005

Cianelli D, D’Alelio D, Uttieri M, Sarno D, Zingone A, Zambianchi E, d'Alcalà MR (2017) Disentangling physical and biological drivers of phytoplankton dynamics in a coastal system. Scientific Reports 7(1): 15868. https://doi.org/10.1038/s41598-017-15880-x

Cloern JE, Jassby AD (2012) Drivers of change in estuarine-coastal ecosystems: Discoveries from four decades of study in San Francisco Bay. Reviews of Geophysics 50(4): RG4001. https://doi.org/10.1029/2012RG000397

Cloern JE, Abreu PC, Carstensen J, Chauvaud L, Elmgren R, Grall J, Greening H, Johansson JOR, Kahru M, Sherwood ET, Xu J, Yin K (2016) Human activities and climate variability drive fast-paced change across the world's estuarine-coastal ecosystems. Global Change Biology 22(2): 513-529. https://doi.org/10.1111/gcb.13059

Corriero G, Pierri C, Accoroni S, Alabiso G, Bavestrello G, Barbone E, Bastianini M, Bazzoni AM, Aubry FB, Boero F, Buia MC, Cabrini M, Camatti E, Cardone F, Cataletto B, Vietti RC, Cecere E, Cibic T, Colangelo P, Olazabal AD, D’Onghia G, Finotto S, Fiore N, Fornasaro D, Fraschetti S, Giangrande A, Gravili C, Longo C, Lorenti M, Lugliè A, Maiorano P, Mazzocchi MG, Mercurio M, Mastrototaro F, Mistri M, Monti M, Munari C, Musco L, Nonnis-Marzano C, Padedda BM, Patti FP, Petrocelli A, Piraino S, Portacci G, Pugnetti A, Pulina S, Romagnoli T, Rosati I, Sarno D, Satta CT, Sechi N, Schiapparelli S, Scipione B, Sion L, Terlizzi A, Tirelli V, Totti C, Tursi A, Ungaro N, Zingone A, Zupo V, Basset A (2016) Ecosystem vulnerability to alien and invasive species: A case study on marine habitats along the Italian coast. Aquatic Conservation 26(2): 392-409. https://doi.org/10.1002/aqc.2550 Costa OG (1858) Fauna del Regno di Napoli. Infusori. Azzolino, Napoli, 24 pp.

D'Alelio D, Ruggiero MV (2015) Interspecific plastidial recombination in the diatom genus Pseudo-nitzschia. Journal of Phycology 51(6): 1024-1028. https://doi.org/10.1111/jpy.12350

D’Alelio D, Amato A, Kooistra WHCF, Procaccini G, Casotti R, Montresor M (2009a) Internal Transcribed Spacer polymorphism in Pseudo-nitzschia multistriata (Bacillariophyceae) in the Gulf of Naples: Recent divergence or intraspecific hybridization? Protist 160(1): 9-20. https://doi.org/10.1016/j.protis.2008.07.001

D'Alelio D, Amato A, Luedeking A, Montresor M (2009b) Sexual and vegetative phases in the planktonic diatom Pseudo-nitzschia multistriata. Harmful Algae 8(2): 225-232. https:// doi.org/10.1016/j.hal.2008.05.004

D’Alelio D, Ribera d'Alcalà M, Dubroca L, Sarno D, Zingone A, Montresor M (2010) The time for sex: A biennial life cycle in a marine planktonic diatom. Limnology and Oceanography 55(1): 106-114. https://doi.org/10.4319/lo.2010.55.1.0106

D’Alelio D, Mazzocchi MG, Montresor M, Sarno D, Zingone A, Di Capua I, Franzè G, Margiotta F, Saggiomo M, Ribera d'Alcalà M (2015) The green-blue swing: Plasticity of plankton food-webs in response to coastal oceanographic dynamics. Marine Ecology (Berlin) 36(4): 1155-1170. https://doi.org/10.1111/maec.12211

D’Alelio D, Libralato S, Wyatt T, Ribera d'Alcalà M (2016a) Ecological-network models link diversity, structure and function in the plankton food-web. Scientific Reports 6(1): 21806. https://doi.org/10.1038/srep21806 
D’Alelio D, Montresor M, Mazzocchi MG, Margiotta F, Sarno D, Ribera d'Alcalà M (2016b) Plankton food webs: To what extent can they be simplified? Advances in Oceanography and Limnology 7(1): 67-92. https://doi.org/10.4081/aiol.2016.5646

D’Onofrio G, Marino D, Bianco L, Busico E, Montresor M (1999) Toward an assessment on the taxonomy of dinoflagellate that produce calcareous cysts (Calciodinelloideae, Dinophyceae): A morphological and molecular approach. Journal of Phycology 35(5): 10631078. https://doi.org/10.1046/j.1529-8817.1999.3551063.x

Daday E (1888) Systematische Übersicht der Dinoflagellaten des Golfes von Neapel. Termész Füzetek 11: 98-106.

Davies N, Field D, Amaral-Zettler L, Clark MS, Deck J, Drummond A, Faith DP, Geller J, Gilbert J, Glöckner FO, Hirsch P, Leong J-A, Meyer C, Obst M, Planes S, Scholin C, Vogler AP, Gates RD, Toonen R, Berteaux-Lecellier V, Barbier M, Barker K, Bertilsson S, Bicak M, Bietz MJ, Bobe J, Bodrossy L, Borja A, Coddington J, Fuhrman J, Gerdts G, Gillespie R, Goodwin K, Hanson PC, Hero J-M, Hoekman D, Jansson J, Jeanthon C, Kao R, Klindworth A, Knight R, Kottmann R, Koo MS, Kotoulas G, Lowe AJ, Marteinsson VT, Meyer F, Morrison N, Myrold DD, Pafilis E, Parker S, Parnell JJ, Polymenakou PN, Ratnasingham S, Roderick GK, Rodriguez-Ezpeleta N, Schonrogge K, Simon N, Valette-Silver NJ, Springer Y, Stone GN, Stones-Havas S, Sansone S-A, Thibault KM, Wecker P, Wichels A, Wooley JC, Yahara T, Zingone A (2014) The founding charter of the Genomic Observatories Network. GigaScience 3(1): 2. https://doi. org/10.1186/2047-217X-3-2

De Angelis CM (1958) Seasonal variation of plankton collected in the Gulf of Naples during 1954-1955. Rapp Comm int Mer Médit 14: 245-254.

de Vargas C, Audic S, Henry N, Decelle J, Mahé F, Logares R, Lara E, Berney C, Le Bescot N, Probert I, Carmichael M, Poulain J, Romac S, Colin S, Aury J-M, Bittner L, Chaffron S, Dunthorn M, Engelen S, Flegontova O, Guidi L, Horák A, Jaillon O, Lima-Mendez G, Lukeš J, Malviya S, Morard R, Mulot M, Scalco E, Siano R, Vincent F, Zingone A, Dimier C, Picheral M, Searson S, Kandels-Lewis S, Coordinators TO, Acinas SG, Bork P, Bowler C, Gorsky G, Grimsley N, Hingamp P, Iudicone D, Not F, Ogata H, Pesant S, Raes J, Sieracki ME, Speich S, Stemmann L, Sunagawa S, Weissenbach J, Wincker P, Karsenti E (2015) Eukaryotic plankton diversity in the sunlit ocean. Science 348(6237): 1261605. https://doi.org/10.1126/science.1261605

Degerlund M, Huseby S, Zingone A, Sarno D, Landfald B (2012) Functional diversity in cryptic species of Chaetoceros socialis Lauder (Bacillariophyceae). Journal of Plankton Research 34(5): 416-431. https://doi.org/10.1093/plankt/fbs004

Delle Chiaje S (1823) Memorie sulla storia e notomia degli animali senza vertebre del Regno di Napoli. Dalla stamperia de' Fratelli Fernandes, Napoli, 184 pp. https://doi.org/10.5962/ bhl.title. 10021

Di Capua I, Mazzocchi MG (2004) Population structure of the copepods Centropages typicus and Temora stylifera in different environmental conditions. ICES Journal of Marine Science 61(4): 632-644. https://doi.org/10.1016/j.icesjms.2004.03.007

Di Capua I, Mazzocchi MG (2017) Non-predatory mortality in Mediterranean coastal copepods. Marine Biology 164(10): 198. https://doi.org/10.1007/s00227-017-3212-z 
Di Capua I, Maffucci F, Pannone R, Mazzocchi MG, Biffali E, Amato A (2017) Molecular phylogeny of Oncaeidae (Copepoda) using nuclear ribosomal internal transcribed spacer (ITS rDNA). PLoS One 12(4): e0175662. https://doi.org/10.1371/journal.pone.0175662

Duarte CM, Cebrian J, Marba N (1992) Uncertainty of detecting sea change. Nature 356(6366): 190. https://doi.org/10.1038/356190a0

Edwards M, Beaugrand G, Hays GC, Koslow JA, Richardson AJ (2010) Multi-decadal oceanic ecological datasets and their application in marine policy and management. Trends in Ecology \& Evolution 25(10): 602-610. https://doi.org/10.1016/j.tree.2010.07.007

Escalera L, Benvenuto G, Scalco E, Zingone A, Montresor M (2014) Ultrastructural features of the benthic dinoflagellate Ostreopsis cf. ovata (Dinophyceae). Protist 165(3): 260-274. https://doi.org/10.1016/j.protis.2014.03.001

Escalera L, Italiano A, Pistocchi R, Montresor M, Zingone A (2018) Gonyaulax hyalina and G. fragilis (Dinoflagellata), two names associated with 'mare sporco', indicate the same species. Phycologia 57(4): 453-464. https://doi.org/10.2216/17-64.1

Finlay BJ (2002) Global dispersal of free-living microbial eukaryote species. Science 296(5570): 1061-1063. https://doi.org/10.1126/science.1070710

Forster D, Dunthorn M, Mahé F, Dolan J, Audic S, Bass D, Bittner L, Boutte C, Christen R, Claverie J, Decelle J, Edvardsen B, Egge E, Eikrem W, Gobet A, Kooistra WCHF, Logares R, Massana R, Montresor M, Not F, Ogata H, Pawlowski J, Pernice MC, Romac S, Shalchian-Tabrizi K, Simon N, Richards TA, Santini S, Sarno D, Siano R, Vaulot D, Wincker P, Zingone A, De Vargas C, Stoeck T (2016) Benthic protists: The under-charted majority. FEMS Microbiology Ecology 92(8): fiw120. https://doi.org/10.1093/femsec/fiw120

Franzè G, Modigh M (2013) Experimental evidence for internal predation in microzooplankton communities. Marine Biology 160(12): 3103-3112. https://doi.org/10.1007/s00227013-2298-1

French FW, Hargraves PE (1986) Population dynamics of the spore-forming diatom Leptocylindrus danicus in Narragansett Bay, Rhode Island. Journal of Phycology 22(4): 411-420. https://doi.org/10.1111/j.1529-8817.1986.tb02482.x

Gaonkar CC (2016) Diversity, distribution and evolution of the planktonic diatom family Chaetocerotaceae. PhD thesis The Open University. http://oro.open.ac.uk/id/eprint/50352

Gaonkar CC, Piredda R, Minucci C, Mann DG, Montresor M, Sarno D, Kooistra WHCF (2018) Annotated $18 S$ and 28S rDNA reference sequences of taxa in the planktonic diatom family Chaetocerotaceae, PLoS ONE, 13:e0208929. https://doi.org/10.1371/journal.pone.0208929

Giesbrecht W (1892) Systematik und Faunistik der pelagischen Copepoden des Golfes von Neapel und der angrenzenden Meeres-Abschnitte. R. Friedlander \& Sohn: 1-831. https://doi.org/10.5962/bhl.title.59541

Harris R (2010) The L4 time-series: The first 20 years. Journal of Plankton Research 32(5): 577-583. https://doi.org/10.1093/plankt/fbq021

Harris V, Edwards M, Olhede SC (2014) Multidecadal Atlantic climate variability and its impact on marine pelagic communities. Journal of Marine Systems 133: 55-69. https://doi. org/10.1016/j.jmarsys.2013.07.001 
Hirai J, Katakura S, Kasai H, Nagai S (2017) Cryptic zooplankton diversity revealed by a metagenetic approach to monitoring metazoan communities in the coastal waters of the Okhotsk Sea, Northeastern Hokkaido. Frontiers in Marine Science 4: 379. https://doi. org/10.3389/fmars.2017.00379

Hughes BB, Beas-Luna R, Barner AK, Brewitt K, Brumbaugh DR, Cerny-Chipman EB, Close SL, Coblentz KE, De Nesnera KL, Drobnitch ST, Figurski JD, Focht B, Friedman M, Freiwald J, Heady KK, Heady WN, Hettinger A, Johnson A, Karr KA, Mahoney B, Moritsch MM, Osterback A-MK, Reimer J, Robinson J, Rohrer T, Rose JM, Sabal M, Segui LM, Shen C, Sullivan J, Zuercher R, Raimondi PT, Menge BA, Grorud-Colvert K, Novak M, Carr MH (2017) Long-term studies contribute disproportionately to ecology and policy. Bioscience 67(3): 271-281. https://doi.org/10.1093/biosci/biw185

Hure J, Scotto di Carlo B (1968) Comparazione tra lo zooplancton del Golfo di Napoli e dell'Adriatico meridionale presso Dubrovnik. Pubblicazioni della Stazione Zoologica di Napoli 36: 21-102.

Huseby S, Degerlund M, Zingone A, Hansen E (2012) Metabolic fingerprinting reveals differences between northern and southern strains of the cryptic diatom Chaetoceros socialis. European Journal of Phycology 47(4): 480-489. https://doi.org/10.1080/09670262.2012.741714

Ianora A (1998) Copepod life history traits in subtemperate regions. Journal of Marine Systems 15(1-4): 337-349. https://doi.org/10.1016/S0924-7963(97)00085-7

Ianora A, Buttino I (1990) Seasonal cycles in population abundances and egg production rates in the planktonic copepods Centropages typicus and Acartia clausi. Journal of Plankton Research 12(3): 473-481. https://doi.org/10.1093/plankt/12.3.473

Ianora A, Miralto A (2010) Toxigenic effects of diatoms on grazers, phytoplankton and other microbes: A review. Ecotoxicology (London, England) 19(3): 493-511. https://doi. org/10.1007/s10646-009-0434-y

Ianora A, Poulet SA (1993) Egg viability in the copepod Temora stylifera. Limnology and Oceanography 38(8): 1615-1626. https://doi.org/10.4319/lo.1993.38.8.1615

Ianora A, Mazzocchi MG, Scotto Di Carlo B (1987) Impact of parasitism and intersexuality on Mediterranean populations of Paracalanus parvus (Copepoda: Calanoida). Diseases of Aquatic Organisms 3: 29-36. https://doi.org/10.3354/dao003029

Ianora A, Scotto di Carlo B, Mazzocchi MG, Mascellaro P (1990) Histomorphological changes in the reproductive condition of parasitized marine planktonic copepods. Journal of Plankton Research 12(2): 249-258. https://doi.org/10.1093/plankt/12.2.249

Ianora A, Mazzocchi MG, Grottoli R (1992) Seasonal fluctuations in fecundity and hatching success in the planktonic copepod Centropages typicus. Journal of Plankton Research 14(11): 1483-1494. https://doi.org/10.1093/plankt/14.11.1483

Iermano I, Liguori G, Iudicone D, Buongiorno Nardelli B, Colella S, Zingone A, Saggiomo V, Ribera d'Alcalà M (2012) Filament formation and evolution in buoyant coastal waters: Observation and modelling. Progress in Oceanography 106: 118-137. https://doi. org/10.1016/j.pocean.2012.08.003

Indelli E (1944) Il microplankton di superficie del Golfo di Napoli. Acta Pontificia Academia Scientiarum 8: 91-100. 
Issel R (1934) Ciclo annuale del microplancton di superficie nel golfo di Napoli (golfo interno) (Introduzione illustrata all'indagine ecologica). Pubblicazioni della Stazione Zoologica di Napoli 14: 1-50.

John U, Litaker W, Montresor M, Murray S, Brosnahan M, Anderson DM (2014) Formal revision of the Alexandrium tamarense species complex (Dinophyceae) taxonomy: The introduction of five species with emphasis on molecular-based (rDNA) classification. Protist 165(6): 779-804. https://doi.org/10.1016/j.protis.2014.10.001

Johnson CL, Leising AW, Runge JA, Head EJH, Pepin P, Plourde S, Durbin EG (2008) Characteristics of Calanus finmarchicus dormancy patterns in the Northwest Atlantic. ICES Journal of Marine Science 65(3): 339-350. https://doi.org/10.1093/icesjms/fsm171

Karl DM (2010) Oceanic ecosystem time-series programs: Ten lessons learned. Oceanography (Washington, D.C.) 23(3): 104-125. https://doi.org/10.5670/oceanog.2010.27

Karl DM, Bidigare RR, Letelier RM (2001) Long term changes in plankton community structure and productivity in the North Pacific Subtropical Gyre: The domain shift hypothesis. Deep-sea Research. Part II, Topical Studies in Oceanography 48(8-9): 1449-1470. https://doi.org/10.1016/S0967-0645(00)00149-1

Kasapidis P, Siokou I, Khelifi-Touhami M, Mazzocchi MG, Matthaiaki M, Christou E, Fernandez de Puelles ML, Gubanova A, Di Capua I, Batziakas S, Frangoulis C (2018) Revising the taxonomic status and distribution of the Paracalanus parvus species complex (Copepoda, Calanoida) in the Mediterranean and Black Seas through an integrated analysis of morphology and molecular taxonomy. Journal of Plankton Research 40(5): 595-605. https://doi.org/10.1093/plankt/fby036

Kooistra WHCF, Sarno D, Balzano S, Gu H, Andersen RA, Zingone A (2008) Global diversity and biogeography of Skeletonema species (Bacillariophyta). Protist 159(2): 177-193. https://doi.org/10.1016/j.protis.2007.09.004

Kooistra WHCF, Sarno D, Hernández-Becerril DU, Assmy P, Di Prisco C, Montresor M (2010) Comparative molecular and morphological phylogenetic analyses of taxa in the Chaetocerotaceae (Bacillariophyta). Phycologia 5(5): 471-500. https://doi.org/10.2216/09-59.1

Koslow JA, Couture J (2013) Ocean sciences: Follow the fish. Nature 502(7470): 163-164. https://doi.org/10.1038/502163a

Koslow JA, Goericke R, Lara-Lopez A, Watson W (2011) Impact of declining intermediatewater oxygen on deepwater fishes in the California Current. Marine Ecology Progress Series 436: 207-218. https://doi.org/10.3354/meps09270

Lamari N, Ruggiero MV, d'Ippolito G, Kooistra WHCF, Fontana A, Montresor M (2013) Specificity of lipoxygenase pathways supports species delineation in the marine diatom genus Pseudo-nitzschia. PLoS One 8(8): e73281. https://doi.org/10.1371/journal.pone.0073281

Levialdi Ghiron JH, Amato A, Montresor M, Kooistra WCHF (2008) Plastid inheritance in the planktonic raphid pennate diatom Pseudo-nitzschia delicatissima (Bacillariophyceae). Protist 159(1): 91-98. https://doi.org/10.1016/j.protis.2007.06.002

Logares R, Audic S, Bass D, Bittner L, Boutte C, Christen R, Claverie J-M, Decelle J, Dolan JR, Dunthorn M, Edvardsen B, Gobet A, Kooistra WCHF, Mahé F, Not F, Ogata H, Pawlowski J, Pernice MC, Romac S, Shalchian-Tabrizi K, Simon N, Stoeck T, Santini S, Siano R, Wincker P, Zingone A, Richards TA, de Vargas C, Massana R (2014) Patterns of rare 
and abundant marine microbial eukaryotes. Current Biology 24(8): 813-821. https://doi. org/10.1016/j.cub.2014.02.050

Loreau M (2010) Linking biodiversity and ecosystems: Towards a unifying ecological theory. Philosophical Transactions of the Royal Society of London. Series B, Biological Sciences 365(1537): 49-60. https://doi.org/10.1098/rstb.2009.0155

Mackas D, Greve W, Edwards M, Chiba S, Tadokoro K, Eloire D, Mazzocchi M, Batten S, Richardson A, Johnson C, Head E, Conversi A, Peluso T (2012) Changing zooplankton seasonality in a changing ocean: Comparing time series of zooplankton phenology. Progress in Oceanography 97: 31-62. https://doi.org/10.1016/j.pocean.2011.11.005

Mahadik GA (2014) The role of copepod grazing in the dynamics of phytoplankton blooms. $\mathrm{PhD}$ thesis The Open University.

Mahadik GA, Castellani C, Mazzocchi MG (2017) Effect of diatom morphology on the smallscale behavior of the copepod Temora stylifera (Dana, 1849). Journal of Experimental Marine Biology and Ecology 493: 41-48. https://doi.org/10.1016/j.jembe.2017.05.001

Marino D, Modigh M, Zingone A (1984) General features of phytoplankton communities and primary production in the Gulf of Naples and adjacent waters. In: Holm-Hansen O, Bolis L, Gilles R (Eds) Marine Phytoplankton and Productivity. Springer-Verlag, Berlin, 89-100. https://doi.org/10.1029/LN008p0089

Marino D, Montresor M, Zingone A (1987) Miraltia throndsenii gen. nov., sp. nov., a planctonic diatom from the Gulf of Naples. Diatom Research 2(2): 205-211. https://doi.org/1 0.1080/0269249X.1987.9704998

Marino D, Giuffé G, Montresor M, Zingone A (1991) An electron microscope investigation on Chaetoceros minimus (Levander) comb. nov. and new observations on Chaetoceros throndsenii (Marino, Montresor and Zingone) comb. nov. Diatom Research 6(2): 317326. https://doi.org/10.1080/0269249X.1991.9705177

Massana R, Gobet A, Audic S, Bass D, Bittner L, Boutte C, Chambouvet A, Christen R, Claverie JM, Decelle J, Dolan JR, Dunthorn M, Edvardsen B, Forn I, Forster D, Guillou L, Jaillon O, Kooistra WHCF, Logares R, Mahé F, Not F, Ogata H, Pawlowski J, Pernice MC, Probert I, Romac S, Richards T, Santini S, Shalchian-Tabrizi K, Siano R, Simon N, Stoeck T, Vaulot D, Zingone A, de Vargas C (2015) Marine protist diversity in European coastal waters and sediments as revealed by high-throughput sequencing. Environmental Microbiology 17(10): 4035-4049. https://doi.org/10.1111/14622920.12955

Mazzocchi MG, Ribera d'Alcalà M (1995) Recurrent patterns in zooplankton structure and succession in a variable coastal environment. ICES Journal of Marine Science 52(3-4): 679-691. https://doi.org/10.1016/1054-3139(95)80081-6

Mazzocchi MG, Buffoni G, Carotenuto Y, Pasquali S, Ribera d'Alcalà M (2006) Effects of food conditions on the development of the population of Temora stylifera: A modeling approach. Journal of Marine Systems 62(1-2): 71-84. https://doi.org/10.1016/j. jmarsys.2006.04.005

Mazzocchi MG, Licandro P, Dubroca L, Di Capua I, Saggiomo V (2011) Zooplankton associations in a Mediterranean long-term time-series. Journal of Plankton Research 33(8): 1163-1181. https://doi.org/10.1093/plankt/fbr017 
Mazzocchi MG, Dubroca L, Garcia-Comas C, Di Capua I, d'Alcalà MR (2012) Stability and resilience in coastal copepod assemblages: The case of the Mediterranean long-term ecological research at Station MC (LTER-MC). Progress in Oceanography 97: 135-151. https://doi.org/10.1016/j.pocean.2011.11.003

McDonald SM, Sarno D, Scanlan DJ, Zingone A (2007a) Genetic diversity of eukaryotic ultraphytoplankton in the Gulf of Naples during an annual cycle. Aquatic Microbial Ecology 50: 75-89. https://doi.org/10.3354/ame01148

McDonald SM, Sarno D, Zingone A (2007b) Identifying Pseudo-nitzschia species in natural samples using genus-specific PCR primers and clone libraries. Harmful Algae 6(6): 849860. https://doi.org/10.1016/j.hal.2007.03.003

McGowan JA (1990) Climate and change in oceanic ecosystems: The value of time-series data. Trends in Ecology \& Evolution 5(9): 293-298. https://doi.org/10.1016/01695347(90)90084-Q

McNamee SE, Medlin LK, Kegel J, McCoy GR, Raine R, Barra L, Ruggiero MV, Kooistra WHCF, Montresor M, Hagstrom J, Blanco EP, Graneli E, Rodríguez F, Escalera L, Reguera B, Dittami S, Edvardsen B, Taylor J, Lewis JM, Pazos Y, Elliott CT, Campbell K (2016) Distribution, occurrence and biotoxin composition of the main shellfish toxin producing microalgae within European waters: A comparison of methods of analysis. Harmful Algae 55: 112-120. https://doi.org/10.1016/j.hal.2016.02.008

Meunier A (1915) Microplankton de la Mer Flamande: 2. Les Diatomacées (suite) (Le Genre Chaetoceros excepté). Mémoires du Musée Royal d'Histoire Naturelle de Belgique 7: $1-118$.

Mirtl M, Borer E, Djukic I, Forsius M, Haubold H, Hugo W, Jourdan J, Lindenmayer D, McDowell W, Muraoka H (2018) Genesis, goals and achievements of long-term ecological research at the global scale: A critical review of ILTER and future directions. The Science of the Total Environment 626: 1439-1462. https://doi.org/10.1016/j.scitotenv.2017.12.001

Modigh M (2001) Seasonal variations of photosynthetic ciliates at a Mediterranean coastal site. Aquatic Microbial Ecology 23: 163-175. https://doi.org/10.3354/ame023163

Modigh M, Castaldo S (2002) Variability and persistence in tintinnid populations at a Mediterranean coastal site. Aquatic Microbial Ecology 28: 299-311. https://doi.org/10.3354/ ame028299

Modigh M, Franzè G (2009) Changes in phytoplankton and microzooplankton populations during grazing experiments at a Mediterranean coastal site. Journal of Plankton Research 31(8): 853-864. https://doi.org/10.1093/plankt/fbp035

Modigh M, Saggiomo V, Ribera d'Alcalà M (1996) Conservative features of picoplankton in a Mediterranean eutrophic area, the Bay of Naples. Journal of Plankton Research 18(1): 87-95. https://doi.org/10.1093/plankt/18.1.87

Montresor M (1995) Scrippsiella ramonii sp. nov. (Peridiniales, Dinophyceae), a marine dinoflagellate producing a calcareous resting cyst. Phycologia 34(1): 87-91. https://doi.org/10.2216/i0031-8884-34-1-87.1

Montresor M, Zingone A (1988) Scrippsiella precaria sp. nov. (Dinophyceae) a marine dinoflagellate from the Gulf of Naples. Phycologia 27(3): 387-394. https://doi.org/10.2216/ i0031-8884-27-3-387.1 
Montresor M, Zingone A, Marino D (1993) The calcareous resting cyst of Pentapharsodinium tyrrhenicum comb. nov. (Dinophyceae). Journal of Phycology 29(2): 223-230. https://doi. org/10.1111/j.0022-3646.1993.00223.x

Montresor M, Montesarchio E, Marino D, Zingone A (1994) Calcareous dinoflagellate cysts in marine sediments of the Gulf of Naples (Mediterranean Sea). Review of Palaeobotany and Palynology 84(1-2): 45-56. https://doi.org/10.1016/0034-6667(94)90040-X

Montresor M, Zingone A, Sarno D (1998) Dinoflagellate cyst production at a coastal Mediterranean site. Journal of Plankton Research 20(12): 2291-2312. https://doi.org/10.1093/ plankt/20.12.2291

Montresor M, Sgrosso S, Procaccini G, Kooistra WHCF (2003) Intraspecific diversity in Scrippsiella trochoidea (Dinophyceae): Evidence for cryptic species. Phycologia 42(1): 5670. https://doi.org/10.2216/i0031-8884-42-1-56.1

Montresor M, John U, Beran A, Medlin LK (2004) Alexandrium tamutum sp. nov. (Dinophyceae): A new nontoxic species in the genus Alexandrium. Journal of Phycology 40(2): 398-411. https://doi.org/10.1111/j.1529-8817.2004.03060.x

Montresor M, Di Prisco C, Sarno D, Margiotta F, Zingone A (2013) Diversity and germination patterns of diatom resting stages at a coastal Mediterranean site. Marine Ecology Progress Series 484: 79-95. https://doi.org/10.3354/meps10236

Montresor M, Vitale L, D’Alelio D, Ferrante MI (2016) Sex in marine planktonic diatoms: Insights and challenges. Perspectives in Phycology 3(2): 61-75. https://doi.org/10.1127/ $\mathrm{pip} / 2016 / 0045$

Moon-van der Staay SY, De Wachter R, Vaulot D (2001) Oceanic 18S rDNA sequences from picoplankton reveal unsuspected eukaryotic diversity. Nature 409(6820): 607-610. https://doi.org/10.1038/35054541

Morabito G, Mazzocchi MG, Salmaso N, Zingone A, Bergami C, Flaim G, Accoroni S, Basset A, Bastianini M, Belmonte G, Bernardi Aubry F, Bertani I, Bresciani M, Buzzi F, Cabrini M, Camatti E, Caroppo C, Cataletto B, Castellano M, Del Negro P, de Olazabal A, Di Capua I, Elia AC, Fornasaro D, Giallain M, Grilli F, Leoni B, Lipizer M, Longobardi L, Ludovisi A, Lugliè A, Manca M, Margiotta F, Mariani MA, Marini M, Marzocchi M, Obertegger U, Oggioni A, Padedda BM, Pansera M, Piscia R, Povero P, Pulina S, Romagnoli T, Rosati I, Rossetti G, Rubino F, Sarno D, Satta CT, Sechi N, Stanca E, Tirelli V, Totti C, Pugnetti A (2018) Plankton dynamics across the freshwater, transitional and marine research sites of the LTER-Italy Network. Patterns, fluctuations, drivers. The Science of the Total Environment 627: 373-387. https://doi.org/10.1016/j.scitotenv.2018.01.153

Nanjappa D, Kooistra WHCF, Zingone A (2013) A reappraisal of the genus Leptocylindrus (Bacillariophyta), with the addition of three species and the erection of Tenuicylindrus gen. nov. Journal of Phycology 49: 917-936. https://doi.org/10.1111/jpy.12102

Nanjappa D, Audic S, Romac S, Kooistra WCHF, Zingone A (2014a) Assessment of species diversity and distribution of an ancient diatom lineage using a DNA metabarcoding approach. PLoS One 9(8): e103810. https://doi.org/10.1371/journal.pone.0103810

Nanjappa D, d'Ippolito G, Gallo C, Zingone A, Fontana A (2014b) Oxylipin diversity in the diatom family Leptocylindraceae reveals DHA derivatives in marine diatoms. Marine Drugs 12(1): 368-384. https://doi.org/10.3390/md12010368 
Nanjappa D, Sanges R, Ferrante MI, Zingone A (2017) Diatom flagellar genes and their expression during sexual reproduction in Leptocylindrus danicus. BMC Genomics 18(1): 813. https://doi.org/10.1186/s12864-017-4210-8

Nixon SW (1995) Coastal marine eutrophication: A definition, social causes, and future concerns. Ophelia 41(1): 199-219. https://doi.org/10.1080/00785236.1995.10422044

Orsini L, Sarno D, Procaccini G, Poletti R, Dahlmann J, Montresor M (2002) Toxic Pseudonitzschia multistriata (Bacillariophyceae) from the Gulf of Naples: Morphology, toxin analysis and phylogenetic relationships with other Pseudo-nitzschia species. European Journal of Phycology 37(2): 247-25. https://doi.org/10.1017/S0967026202003608

Orsini L, Procaccini G, Sarno D, Montresor M (2004) Multiple rDNA ITS-types within the diatom Pseudo-nitzschia delicatissima (Bacillariophyceae) and their relative abundances across a spring bloom in the Gulf of Naples. Marine Ecology Progress Series 271: 87-98. https://doi.org/10.3354/meps271087

Pargana A (2017) Functional and molecular diversity of the diatom family Leptocylindraceae. $\mathrm{PhD}$ thesis The Open University. http://oro.open.ac.uk/id/eprint/50238

Patil S, Moeys S, von Dassow P, Huysman MJJ, Mapleson D, De Veylder L, Sanges R, Vyverman W, Montresor M, Ferrante MI (2015) Identification of the meiotic toolkit in diatoms and exploration of meiosis-specific SPO11 and RAD51 homologs in the sexual species Pseudo-nitzschia multistriata and Seminavis robusta. BMC Genomics 16(1): 930. https://doi.org/10.1186/s12864-015-1983-5

Percopo I, Siano R, Rossi R, Soprano V, Sarno D, Zingone A (2013) A new potentially toxic Azadinium species (Dinophyceae) from the Mediterranean Sea, A. dexteroporum sp. nov. Journal of Phycology 49: 950-966. https://doi.org/10.1111/jpy.12104

Piredda R, Sarno D, Lange CB, Tomasino MP, Zingone A, Montresor M (2017a) Diatom resting stages in surface sediments: A pilot study comparing Next Generation Sequencing and Serial Dilution Cultures. Cryptogamie. Algologie 38(1): 31-46. https://doi.org/10.7872/ crya/v38.iss1.2017.31

Piredda R, Tomasino MP, D’Erchia AM, Manzari C, Pesole G, Montresor M, Kooistra WHCF, Sarno D, Zingone A (2017b) Diversity and temporal patterns of planktonic protist assemblages at a Mediterranean Long Term Ecological Research site. FEMS Microbiology Ecology 93(1): fiw200. https://doi.org/10.1093/femsec/fiw200

Piredda R, Claverie JM, Decelle J, de Vargas C, Dunthorn M, Edvardsen B, Eikrem W, Forster D, Kooistra WHCF, Logares R, Massana R, Montresor M, Not F, Ogata H, Pawlowski J, Romac S, Sarno D, Stoeck T, Zingone A (2018) Diatom diversity through HTS-metabarcoding in coastal European seas. Scientific Reports 8(1): 18059. https://doi.org/10.1038/ s41598-018-36345-9

Pugnetti A, Camatti E, Mangoni O, Morabito G, Oggioni A, Saggiomo V (2006) Phytoplankton production in Italian freshwater and marine ecosystems: State of the art and perspectives. Chemistry and Ecology 22(sup1):S49-S69. https://doi.org/10.1080/02757540600557330

Puigserver M, Zingone A (2002) Prorocentrum nux sp. nov. (Dinophyceae), a small planktonic dinoflagellate from the Gulf of Naples (Mediterranean Sea), and a rediscussion of $P$. nanum and P. pusillum. Phycologia 41(1): 29-38. https://doi.org/10.2216/i0031-8884-41-1-29.1 
Ragosta M, Mazzocchi GM, Macchiato M (1995) Differentiation of copepod assemblages in coastal waters of the Tyrrhenian Sea. Oceanologica Acta 18: 479-491. https://archimer. ifremer.fr/doc/00097/20873/

Reid P, Colebrook J, Matthews J, Aiken J, Team CPR (2003) The Continuous Plankton Recorder: Concepts and history, from plankton indicator to undulating recorders. Progress in Oceanography 58(2-4): 117-173. https://doi.org/10.1016/j.pocean.2003.08.002

Renz J, Hirche H-J (2006) Life cycle of Pseudocalanus acuspes Giesbrecht (Copepoda, Calanoida) in the central Baltic Sea: I seasonal and spatial distribution. Marine Biology 148(3): 567-580. https://doi.org/10.1007/s00227-005-0103-5

Ribera d'Alcalà M (2019) Similarities, differences and mechanisms of climate impact on terrestrial vs. marine ecosystems. In: Mazzocchi MG, Capotondi L, Freppaz M, Lugliè A, Campanaro A (Eds) Italian Long-Term Ecological Research for understanding ecosystem diversity and functioning. Case studies from aquatic, terrestrial and transitional domains. Nature Conservation 34: 505-523. https://doi.org/10.3897/natureconservation.34.30923

Ribera d'Alcalà M, Modigh M, Moretti M, Saggiomo V, Scardi M, Spezie G, Zingone A (1989) Una storia infinita. Eutrofizzazione nella Baia di Napoli. OEbalia (Taranto) XV-1: 491-501. Ribera d'Alcalà M, Conversano F, Corato F, Licandro P, Mangoni O, Marino D, Mazzocchi MG, Modigh M, Montresor M, Nardella M, Saggiomo V, Sarno D, Zingone A (2004) Seasonal patterns in plankton communities in a pluriannual time series at a coastal Mediterranean site (Gulf of Naples): An attempt to discern recurrences and trends. Scientia Marina 68(S1): 65-83. https://doi.org/10.3989/scimar.2004.68s165

Rossi R, Dell'Aversano C, Krock B, Ciminiello P, Percopo I, Tillmann U, Soprano V, Zingone A (2017) Mediterranean Azadinium dexteroporum (Dinophyceae) produces six novel azaspiracids and azaspiracid-35: A structural study by a multi-platform mass spectrometry approach. Analytical and Bioanalytical Chemistry 409(4): 1121-1134. https://doi.org/10.1007/s00216-016-0037-4

Ruggiero MV, Sarno D, Barra L, Kooistra WHCF, Montresor M, Zingone A (2015) Diversity and temporal pattern of Pseudo-nitzschia species (Bacillariophyceae) through the molecular lens. Harmful Algae 42: 15-24. https://doi.org/10.1016/j.hal.2014.12.001

Ruggiero MV, D’Alelio D, Ferrante MI, Santoro M, Vitale L, Procaccini G, Montresor M (2018) Clonal expansion behind a marine diatom bloom. The ISME Journal 12(2): 463472. https://doi.org/10.1038/ismej.2017.181

Sabia L, Zagami G, Mazzocchi MG, Zambianchi E, Uttieri M (2015) Spreading factors of a globally invading coastal copepod. Mediterranean Marine Science 16(2): 460-471. https://doi.org/10.12681/mms.1154

Sabia L, Costanzo A, Ribera d'Alcalà M, Saggiomo V, Zingone A, Margiotta F (2019) Assessing the quality of biogeochemical coastal data: a step-wise procedure. Mediterranean Marine Science. https://doi.org/10.12681/mms.15935

Santamaria G, Cerchia L, Esposito CL, Benvenuto G, Nanjappa D, Sarno D, Zingone A, De Franciscis V, Ribera d'Alcalà M (2015) Aptamers are an innovative and promising tool for phytoplankton taxonomy and biodiversity research. Chemistry and Ecology 31(1): 92-103. https://doi.org/10.1080/02757540.2014.966700 
Sarno D, Zingone A, Marino D (1997) Bacteriastrum parallelum sp. nov., a new diatom from the Gulf of Naples, and new observations on B. furcatum (Chaetocerotaceae, Bacillariophyta). Phycologia 36(4): 257-266. https://doi.org/10.2216/i0031-8884-36-4-257.1

Sarno D, Kooistra WCHF, Medlin LK, Percopo I, Zingone A (2005) Diversity in the genus Skeletonema (Bacillariophyceae). II. An assessment of the taxonomy of $S$. costatum-like species, with the description of four new species. Journal of Phycology 41(1): 151-176. https://doi.org/10.1111/j.1529-8817.2005.04067.x

Sarno D, Kooistra WCHF, Balzano S, Hargraves PE, Zingone A (2007) Diversity in the genus Skeletonema (Bacillariophyceae): III. Phylogenetic position and morphological variability of Skeletonema costatum and Skeletonema grevillei, with the description of Skeletonema ardens sp. nov. Journal of Phycology 43(1): 156-170. https://doi.org/10.1111/j.15298817.2006.00305.x

Sarno D, Zingone A, Montresor M (2010) A massive and simultaneous sex event of two Pseudo-nitzschia species. Deep-sea Research. Part II, Topical Studies in Oceanography 57(3-4): 248-255. https://doi.org/10.1016/j.dsr2.2009.09.012

Schröder B (1900) Das Phytoplankton des Golfes von Neapel nebst vergleichenden Ausblicken auf das des atlantischen Ozeans. Mittheilungen der Zoologischen Station Neapel 14: 1-38.

Scotto Di Carlo B, Tomas CR, Ianora A, Marino D, Mazzocchi MG, Modigh M, Montresor M, Petrillo L, Ribera d'Alcalà M, Saggiomo V, Zingone A (1985) Uno studio integrato dell'ecosistema pelagico costiero del Golfo di Napoli. Nova Thalassia 126: 99-128.

Siano R, Montresor M (2005) Morphology, ultrastructure and feeding behaviour of Protoperidinium vorax sp. nov. (Dinophyceae, Peridiniales). European Journal of Phycology 40(2): 221-232. https://doi.org/10.1080/09670260500128293

Siano R, Kooistra WHCF, Montresor M, Zingone A (2009) Unarmoured and thin-walled dinoflagellates from the Gulf of Naples, with the description of Woloszynskia cincta sp. nov. (Dinophyceae, Suessiales). Phycologia 48(1): 44-65. https://doi.org/10.2216/08-61.1

Stern R, Kraberg A, Bresnan E, Kooistra WHCF, Lovejoy C, Montresor M, Morán XAG, Not F, Salas R, Siano R, Vaulot D, Amaral-Zettler L, Zingone A, Metfies K (2018) Can molecular tools enhance long-term monitoring of marine protists? Journal of Plankton Research 40: 519-536. https://doi.org/10.1093/plankt/fby035

Tesson SVM, Legrand C, van Oosterhout C, Montresor M, Kooistra WH, Procaccini G (2013) Mendelian inheritance pattern and high mutation rates of microsatellite alleles in the diatom Pseudonitzschia multistriata. Protist 164(1): 89-100. https://doi.org/10.1016/j.protis.2012.07.001

Tesson SVM, Montresor M, Procaccini G, Kooistra WHCF (2014) Temporal changes in population structure of a marine planktonic diatom. PLoS One 9(12): e114984. https://doi. org/10.1371/journal.pone.0114984

Thompson RM, Brose U, Dunne JA, Hall Jr RO, Hladyz S, Kitching RL, Martinez ND, Rantala H, Romanuk TN, Stouffer DB, Tylianakis JM (2012) Food webs: Reconciling the structure and function of biodiversity. Trends in Ecology \& Evolution 27(12): 689-697. https://doi.org/10.1016/j.tree.2012.08.005

Throndsen J (1978) The dilution culture method. In: Sournia A (Ed.) Phytoplankton Manual. UNESCO Monographs on Methodology, Paris, 218-224. 
Throndsen J, Zingone A (1988) Tetraselmis wettsteinii (Schiller) Throndsen comb. nov. and its occurrence in Golfo di Napoli. Giornale Botanico Italiano 122(3-4): 227-235. https://doi.org/10.1080/11263508809429402

Throndsen J, Zingone A (1994) Micronomads of the Mediterranean sea. Giornale Botanico Italiano 128(6): 1031-1044. https://doi.org/10.1080/11263509409436468

Throndsen J, Zingone A (1997) Dolichomastix tenuilepis sp. nov., a first insight in the microanatomy of the genus Dolicomastix (Mamiellales, Prasinophyceae, Chlorophyta). Phycologia 36(3): 244-254. https://doi.org/10.2216/i0031-8884-36-3-244.1

Tornero V, Ribera d'Alcalà M (2014) Contamination by hazardous substances in the Gulf of Naples and nearby coastal areas: A review of sources, environmental levels and potential impacts in the MSFD perspective. The Science of the Total Environment 466-467: 820 840. https://doi.org/10.1016/j.scitotenv.2013.06.106

Tunin-Ley A, Ibañez F, Labat J-P, Zingone A, Lemée R (2009) Phytoplankton biodiversity and NW Mediterranean Sea warming: Changes in the dinoflagellate genus Ceratium in the $20^{\text {th }}$ century. Marine Ecology Progress Series 375: 85-99. https://doi.org/10.3354/meps07730

Venrick E, McGowan J, Cayan D, Hayward T (1987) Climate and chlorophyll a: Long-term trends in the central North Pacific. Ocean Science 238: 70-72. https://doi.org/10.1126/ science.238.4823.70

von Dassow P, Montresor M (2011) Unveiling the mysteries of phytoplankton life cycles: Patterns and opportunities behind complexity. Journal of Plankton Research 33(1): 3-12. https://doi.org/10.1093/plankt/fbq137

Zenetos A, Gofas S, Verlaque M, Cinar ME, García Raso JE, Bianchi CN, Morri C, Azzurro E, Bilecenoglu M, Froglia C, Siokou I, Violanti D, Sfriso A, San Martin G, Giangrande A, Katagan T, Ballesteros E, Ramos-Espla AA, Mastrototaro F, Ocana O, Zingone A, Gambi MC, Streftaris N (2010) Alien species in the Mediterranean Sea by 2010. A contribution to the application of European Union's Marine Strategy Framework Directive MSFD). Part I. Spatial distribution. Mediterranean Marine Science 11(2): 381-493. https://doi.org/10.12681/mms.87

Zingone A, Montresor M (1988) Protoperidinium parthenopes sp. nov. (Dinophyceae), an intriguing dinoflagellate from the Gulf of Naples. Cryptogamie. Algologie 9: 117-125.

Zingone A, Sarno D (2001) Recurrent patterns in coastal phytoplankton from the Gulf of Naples. Archivio di Oceanografia e Limnologia 22: 113-118.

Zingone A, Montresor M, Marino D (1990) Summer phytoplankton physiognomy in coastal water of the Gulf of Naples. PSZNI: Marine Ecology 11(2): 157-172. https://doi.org/10.1111/j.1439-0485.1990.tb00236.x

Zingone A, Casotti R, Ribera d'Alcalà M, Scardi M, Marino D (1995a) 'St Martin's Summer': The case of an autumn phytoplankton bloom in the Gulf of Naples (Mediterranean Sea). Journal of Plankton Research 17(3): 575-593. https://doi.org/10.1093/plankt/17.3.575

Zingone A, Throndsen J, Forlani G (1995b) Pyramimonas oltmannsii (Prasinophyceae) reinvestigated. Phycologia 34(3): 241-249. https://doi.org/10.2216/i0031-8884-34-3-241.1

Zingone A, Montresor M, Marino D (1998) Morphological variability of the potentially toxic dinoflagellate Dinophysis sacculus (Dinophyceae) and its taxonomic relationships 
with D. pavillardii and D. acuminata. European Journal of Phycology 33(3): 259-273. https://doi.org/10.1080/09670269810001736763

Zingone A, Chrétiennot-Dinet M-J, Lange M, Medlin L (1999a) Morphological and genetic characterization of Phaeocystis cordata and Phaeocystis jahnii (Prymnesiophyceae), two new species from the Mediterranean Sea. Journal of Phycology 35(6): 1322-1337. https://doi.org/10.1046/j.1529-8817.1999.3561322.x

Zingone A, Sarno D, Forlani G (1999b) Seasonal dynamics of Micromonas pusilla (Prasinophyceae) and its viruses in the Gulf of Naples (Mediterranean Sea). Journal of Plankton Research 21(11): 2143-2159. https://doi.org/10.1093/plankt/21.11.2143

Zingone A, Borra M, Brunet C, Forlani G, Kooistra WHCF, Procaccini G (2002) Phylogenetic position of Crustomastix stigmatica sp. nov. and Dolichomastix tenuilepis in relation to the Mamiellales (Prasinophyceae, Chlorophyta). Journal of Phycology 38(5): 1024-1039. https://doi.org/10.1046/j.1529-8817.2002.t01-1-02035.x

Zingone A, Licandro P, Sarno D (2003) Revising paradigms and myths of phytoplankton ecology using biological time series. In: Briand F (Ed.) Mediterranean Biological Time Series. CIESM Workshop Monographs n² 22, Monaco, 109-114. http://www.ciesm.org/online/ monographs/Split.html

Zingone A, Percopo I, Sims PA, Sarno D (2005) Diversity in the genus Skeletonema (Bacillariophyceae). I. A re-examination of the type material of Skeletonema costatum, with the description of S. grevillei sp. nov. Journal of Phycology 41(1): 140-150. https://doi.org/10.1111/j.1529-8817.2005.04066.x

Zingone A, Natale F, Biffali E, Borra M, Forlani G, Sarno D (2006a) Diversity in morphology, infectivity, molecular characteristics and induced host resistance between two viruses infecting Micromonas pusilla. Aquatic Microbial Ecology 45: 1-14. https://doi.org/10.3354/ame045001

Zingone A, Siano R, D’Alelio D, Sarno D (2006b) Potentially toxic and harmful microalgae from coastal waters of the Campania region (Tyrrhenian Sea, Mediterranean Sea). Harmful Algae 5(3): 321-337. https://doi.org/10.1016/j.hal.2005.09.002

Zingone A, Dubroca L, Iudicone D, Margiotta F, Corato F, Ribera d'Alcalà M, Saggiomo V, Sarno D (2010a) Coastal phytoplankton do not rest in winter. Estuaries and Coasts 33(2): 342-361. https://doi.org/10.1007/s12237-009-9157-9

Zingone A, Phlips EJ, Harrison PA (2010b) Multiscale variability of twenty-two coastal phytoplankton time series: A global scale comparison. Estuaries and Coasts 33(2): 224-229. https://doi.org/10.1007/s12237-009-9261-x

Zingone A, Harrison PJ, Kraberg A, Lehtinen S, McQuatters-Gollop A, O’Brien T, Sun J, Jakobsen HH (2015) Increasing the quality, comparability and accessibility of phytoplankton species composition time-series data. Estuarine, Coastal and Shelf Science 162: 151160. https://doi.org/10.1016/j.ecss.2015.05.024 